\title{
SHOULD U.S. RESTAURANTS ABANDON TIPPING? A REVIEW OF THE ISSUES AND EVIDENCE
}

\author{
MICHAEL LYNN \\ wml3@cornell.edu \\ School of Hotel Administration, \\ Cornell University, Ithaca
}

\begin{abstract}
Recent interest in replacing tipping with service charges or higher service-inclusive menu pricing prompts a review of empirical evidence on the advantages and disadvantages to restaurants of these different compensation systems. The evidence indicates that these different systems affect the attraction and retention of service workers, the satisfaction of customers with service, the actual and perceived costs of eating out, and the costs of hiring employees and doing business. However, I come away from the data believing that biggest reason for restaurateurs to replace tipping is that it takes revenue away from them in the form of lower prices and gives it to servers in the form of excessively high tip income. The biggest reason for restaurateurs to keep tipping is that it allows them to reduce menu prices, which increases demand. Thus, restaurateurs' decisions to keep voluntary tipping or not should ultimately depend on the relative strengths of these benefits. The more that a restaurant's servers are overpaid relative to the back of house and the wealthier and less price-sensitive a restaurant's customers are, the more the owner of that restaurant should consider abandoning tipping. By this reasoning, many upscale, expensive restaurants (especially those in states with no or small tip credits) probably should replace tipping with one of its alternatives.
\end{abstract}

JEL codes: E24; J31; J64

Keywords: Cornell; restaurant industry; tipping; minimum wage;

tipped minimum wage; restaurant employment; tip credits

How to cite: Lynn, Michael (2017), "Should U.S. Restaurants Abandon Tipping? A Review of the Issues and Evidence," Psychosociological Issues in Human Resource Management 5(1): $120-159$.

Received 8 July $2016 \cdot$ Received in revised form 8 August 2016

Accepted 9 August 2016 • Available online 25 August 2016 
Restaurant tipping has come under assault in the last few years with numerous journalists and commentators calling for its abolition. ${ }^{1}$ Moreover, many restaurateurs have heeded these calls, with nearly a dozen restaurants replacing voluntary tipping with either automatic service charges or higher wages paid thru higher menu prices in the last year alone. ${ }^{2}$ Among those eliminating tipping in 2015 were:

- Union Square Hospitality Group in NYC, ${ }^{3}$

- Dirt Candy in NYC, ${ }^{4}$

- Bar Marco in Pittsburgh, ${ }^{5}$

- the Radler in Chicago, ${ }^{6}$

- Coi in San Francisco, ${ }^{7}$

- Manos Nouveau in San Francisco, ${ }^{8}$

- The Walrus and the Carpenter in Seattle, ${ }^{9}$

- Ivar's Seafood in Seattle, ${ }^{10}$

- Victory 44 in Minneapolis, ${ }^{11}$ and

- Upton 43 in Minneapolis. ${ }^{12}$

These moves away from traditional tipping were sparked in large part by recent efforts to increase the minimum wage, which many restaurateurs hope to pay for with the service charges or higher menu prices that replace voluntary tipping. Recent efforts to decrease the tip credit (which allows employers to reduce tipped employees' wages in consideration of receiving tips) also contribute to the anti-tipping movement, because smaller tip credits reduce any financial benefits of tipping and threaten to exacerbate already large and growing wage inequalities between front and back of house staff.

However, these developments are just the latest round in a recurrent debate over the advantages and disadvantages of tipping. Similar experiments with no-tipping policies and restaurant industry calls for the elimination of tipping occurred in the 1980s when a series of new laws increased restaurants' responsibilities for paying taxes on tip income. ${ }^{13}$ Moreover, the 1980 s debate was just a continuation of a broader controversy over tipping that goes back to the early 1900s when the practice was imported into the United States from Europe. ${ }^{14}$

The debate over the advantages and disadvantages to restaurants of using voluntary tips to compensate wait staff becomes louder and more salient when new government regulations such as decreased tip credits threaten to increase the restaurateurs' tip-related costs. However, the issues in that debate transcend the effects of government regulation. Moreover, those issues remain hotly contested in part because so little evidence is available to resolve them and because the little evidence that does exist is either weak or not widely known. In 2006, I attempted to address these problems in a Cornell Hospitality Report that identified the key issues in this debate, reviewed the little available research, and raised questions in need of further research. ${ }^{15}$ That 
report did not have as much impact on the industry or academy as I had hoped, but it did provide a guide for my own program of research on tipping. Consequently, some 10 years after that report, there is more empirical evidence on many of the issues it identified. That new evidence combined with the current interest in abandoning tipping, prompts me to update the earlier report with this article.

That report on tipping and its alternatives was structured around the following eight issues: consumer preferences, price partitioning, price discrimination, server incentives, pay levels, employee recruitment and retention, income tax evasion, and employment discrimination. Those issues remain central to the debate regarding voluntary tipping, but in retrospect, they are too abstract and academic to capture the attention and hold the interest of most people. Therefore, I use a different structure for this report and discuss those eight issues in the context of five interrelated questions that I believe will be of obvious importance and immediate appeal to industry practitioners and the public alike. Those questions are:

1. Does tipping under (or over) pay servers?;

2. Does tipping help (or hurt) efforts to attract and retain good workers?;

3. Does tipping increase (or decrease) customer satisfaction with service?;

4. Does tipping increase demand by reducing the costs of eating out or perceptions of restaurant expensiveness?; and

5. Does tipping increase (or decrease) the costs of doing business?

\section{Does Tipping under- (or over-) Pay Servers?}

Many people believe that tipping together with the tipped sub-minimum wage underpays servers in the sense that their total incomes are often too small to comfortably live on. For example, Sylvia Allegretto and David Cooper report that the median hourly wage (including tips) for waiters and bartenders in the U.S. is only about 60 percent of the median for all U.S. workers $(\$ 10.11$ vs $\$ 16.48$ ) and that the percentage of tipped workers earning poverty level incomes is twice that of non-tipped workers $(12.8 \%$ vs. $6.5 \%) .{ }^{16}$ However, these data are based on self-reports of waiters and bartenders, who are likely to substantially understate their actual incomes in an attempt to reduce their tax liabilities. ${ }^{17}$ Moreover, federal and state laws ensure that total wages (including tips) meet or exceed the regular minimum wage for that jurisdiction, so income levels among low wage workers have more to do with the number of hours worked and with the minimum wage level than with whether that income comes from tips or paid wages. Thus, the idea that tipped servers are paid too little to live comfortably (even if true) has little bearing on the debate about tipping versus other forms of restaurant employee compensation. 
Servers' standards of living notwithstanding, there is a sense in which tipping may overpay servers. One could make a case that tipping pays restaurant servers more than is necessary to ensure a sufficient number of competent workers. Though restaurateurs and commentators stop short of saying that servers are overpaid, many of them complain that servers' tip incomes often exceed those of equally skilled and important non-tipped restaurant workers. ${ }^{18}$ Since waiting tables requires no formal education or previous experience and only brief on-the-job training, there seems to be little economic rationale for paying waiters and waitresses more than cooks, hosts, and other non-tipped restaurant workers. ${ }^{19}$ Assuming that equally competent servers could be recruited at wage levels that attract non-tipped restaurant workers and that tipped servers do earn more than these other workers, then servers are arguably overpaid, and replacing tipping with service charges or higher menu prices would allow restaurateurs to reduce the total payment to servers and to redirect the recovered overpayments to back-of-house wages or other purposes.

Given the documented tendency for tipped workers to hide income, the least reliable evidence regarding income levels is likely to come from employee reports to the government, with more reliable evidence coming from anonymous employee reports to private individuals or organizations, and the most reliable evidence coming from employers. That may be why the U.S. Bureau of Labor Statistics reports that the median hourly income of waiters and waitresses is less than that of cooks (\$9.01 vs $\$ 10.16)$, while three recent non-governmental surveys indicate that tipped restaurant workers make substantially more than non-tipped restaurant workers. ${ }^{20}$ First, a recent compensation and benefits survey of NYC restaurant companies conducted by the NYC Hospitality Alliance found that the median hourly income (including tips) of servers exceeded that of line cooks by 112 percent ( $\$ 27.50$ vs. $\$ 13.00)$ and that of hosts by 99 percent ( $\$ 27.50$ vs $\$ 13.76)$, with this pay discrepancy having a similar magnitude for both casual and fine-dining restaurants. ${ }^{21}$ Second, a recent survey of 1,150 restaurant managers from large metro areas across the United States conducted by researchers at Cornell and Ohio State found that median weekly wages (including tips) of front-of-house employees exceed that of back-of-house employees by 29 percent ( $\$ 464$ vs $\$ 360$ ) in moderately priced restaurants, by 67 percent ( $\$ 673$ vs $\$ 402)$ in casual fine-dining restaurants, and by 80 percent ( $\$ 792$ vs $\$ 441)$ in upscale fine-dining restaurants. ${ }^{22}$ Finally, a survey of 15,000 restaurant employees conducted by Payscale.com found that the median total hourly pay (including tips) for 18 different restaurant jobs was positively related to the percentage of that total pay coming from tips $(\mathrm{r}=.65, \mathrm{n}=18, \mathrm{p}<.003$; see Exhibit 1.1). ${ }^{23}$ Together, these studies provide compelling evidence that tipping does pay restaurant servers substantially more than their non-tipped 
co-workers. This suggests that restaurants replacing tipping with service charges or higher menu prices could pay servers only a portion of the increased revenue (by paying them wages that are more in line with that of their co-workers) and could then use the remainder to pay the back of house more or to increase profits.

Exhibit 1.1. The more restaurant jobs rely on tips as part of compensation, the more those jobs pay per hour.

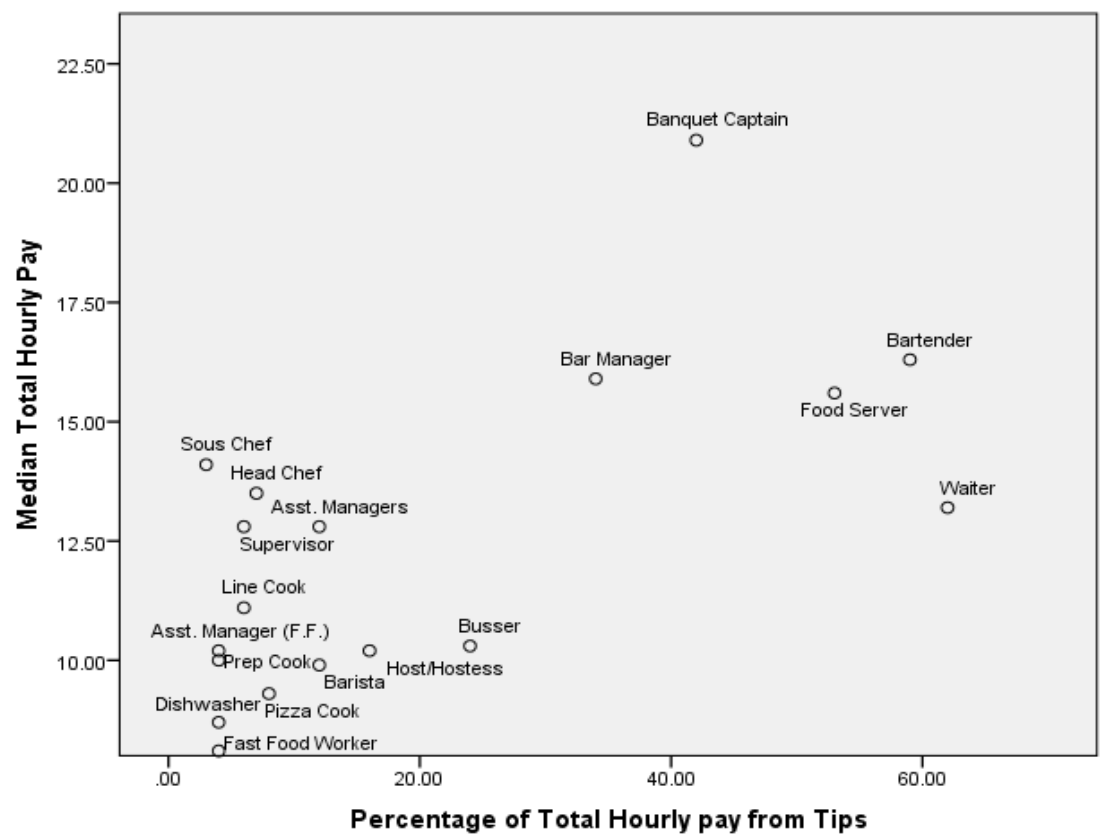

Source of data: Payscale.com.

The greater income that tipped restaurant workers make compared to nontipped restaurant workers occurs despite the fact that the minimum cash wage for tipped workers is often substantially lower than that for non-tipped workers. The difference between tipped and regular minimum wages varies across states, so the wage deficit that tipping must overcome is smaller in some states than others. This means that the pay discrepancy between tipped and non-tipped restaurant workers should be greater in states with smaller tip credits as long as the tip levels do not sizably increase with the states' tip credit. I was able to test this expectation with unpublished data from the survey of restaurant managers by Rosemary Batt and her colleagues, who generously provided me with the needed data. ${ }^{24}$ As expected, the pay premium going to front-of-house workers (at moderate restaurants) was smaller in states with larger tip credits $(\mathrm{r}=-.54, \mathrm{n}=21, \mathrm{p}<.02$; see Exhibit 1.2). This 
finding is important because it suggests that the overpayment of tipped workers and, with it, the case for abandoning tipping is stronger in states with smaller tip credits. It also suggests that reducing or eliminating tip credits, as many are advocating, would exacerbate the overpayment of tipped workers and make the case for abandoning tipping even stronger in the affected states.

Exhibit 1.2. The front of house pay premium is smaller in states with larger tip credits (disparity between regular and tipped minimum wages).

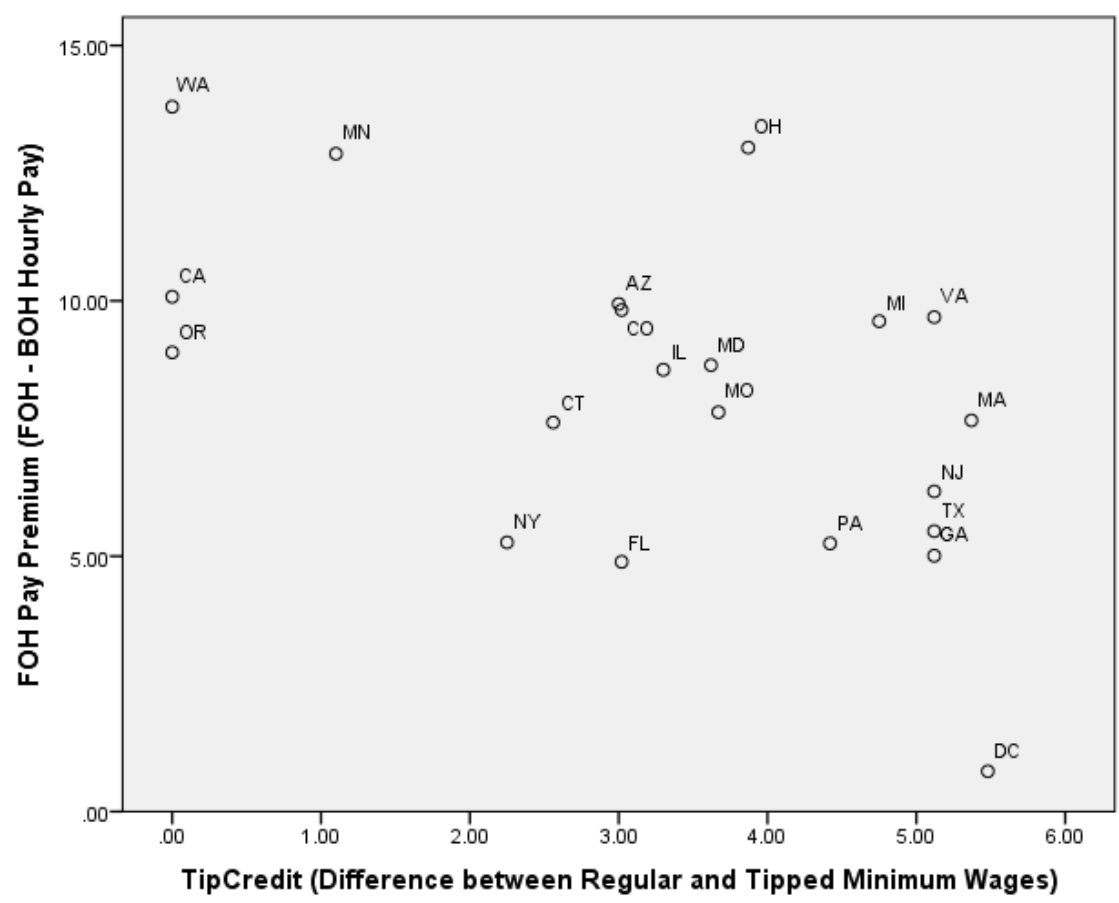

\section{Does Tipping Help (or Hurt) Efforts} to Attract and Retain Good Workers?

Some restaurateurs fear abandoning tipping because they believe it helps them attract and retain better workers. One rationale for this belief is that the pay premium I just discussed may attract higher quality workers into the profession. ${ }^{25} \mathrm{~A}$ second rationale is that the performance-contingent nature of tip income should appeal to and reward competent workers more than less competent ones. ${ }^{26}$

Others argue that tipping may reduce the quality of workers attracted to, and staying in, the restaurant industry. Tip income is inherently variable, which may be unappealing to workers seeking to support themselves and a 
family. ${ }^{27}$ Thus, tipping may attract single workers with a part-time or temporary mentality, thereby undermining efforts to build a professional waitstaff. A definitive assessment of these competing possibilities is not possible, but a number of research findings that speak to these human resource issues are available and are reviewed below.

Do pay premiums attract more and better workers to tipped jobs?

First, let's consider the concern that a reduction in income potential following the elimination of tipping will reduce the number and quality of the applicants for those jobs. Economic theory tells us that better pay should attract more applicants for a job, but it is not clear that the pay premiums tipping gives servers are necessary to fill those service positions with competent workers. Data to test this issue are surprisingly hard to obtain, but if we use job performance as an indicator of worker quality, we can test it with WD Partners' "Consumer Picks Survey" data. Using these data, I calculated average customer service ratings for family-dining and full-service restaurants in 32 states, while controlling for numerous rater characteristics and the restaurant chain being rated. ${ }^{28}$ Those state level service ratings did increase with the previously described 2013 wage gap between front- and back-of-house restaurant employees $(\mathrm{r}=.49, \mathrm{n}=20, \mathrm{p}<.03$; see Exhibit 2.1). However, the increment in average service rating is less than .02 out of 5 points for every dollar that front-of-house employees' hourly pay exceeds that of back-ofhouse employees. ${ }^{29}$ In other words, cutting the excess pay going to servers by $\$ 10$ per hour would reduce average service ratings by only one-fifth of one point on a five point scale. These analyses suggest that the pay premiums associated with tipping do attract somewhat better service workers as reflected in customer ratings of the service levels those workers provide, but not enough to justify those premiums. 
Exhibit 2.1. States with larger pay differences between front- and back-of-house restaurant staff have slightly better restaurant service.

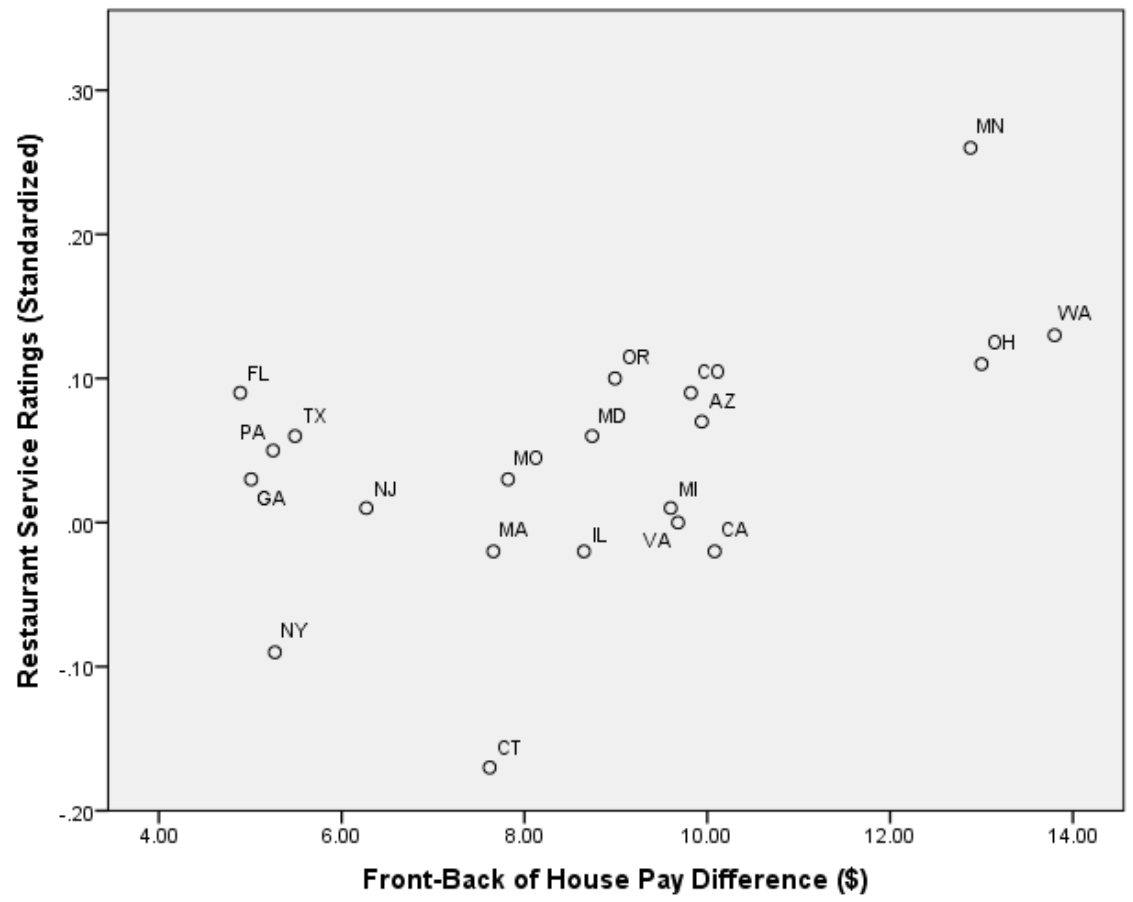

Does the variable and performance-contingent nature of tip income attract more or less desirable applicants and workers?

Second, let's consider the opposing views regarding the effects of tipping's variable and performance-contingent nature. The idea that tipping selectively attracts less desirable workers assumes that only relatively young, less experienced, and part-time workers are willing to put up with the uncertainty of tip income. The opposing idea that tipping selectively attracts more desirable workers assumes that more competent workers earn larger tips and like working for tips more than do less competent workers, and that greater income and liking for the mode of compensation both increase satisfaction with and longevity in tipped jobs (see Exhibit 2.2). Evidence about one or more of these assumed relationships is available from several studies described below.

Exhibit 2.2. Model showing how tipping may help restaurants to selectively attract and retain better workers.

\begin{tabular}{|c|c|c|c|c|}
\hline Worker Quality & & Tipping Mediator & & Attraction/Retention \\
\hline $\begin{array}{l}\text {-Service orientation } \\
\text {-Years experience as } \\
\text { a server }\end{array}$ & $\rightarrow$ & $\begin{array}{l}\text {-Average Tip Size } \\
\text {-Attitude toward } \\
\text { Working for Tips }\end{array}$ & $\rightarrow$ & $\begin{array}{l}\text {-Job Satisfaction } \\
\text {-Intentions/Thoughts/Timing } \\
\text { Quitting Job }\end{array}$ \\
\hline
\end{tabular}


I recently conducted an unpublished survey of a large and diverse, but unrepresentative, sample of the U.S. population, and asked respondents how much they would like or dislike working under different compensation systems if they had to work as a waiter or waitress at a full-service restaurant. ${ }^{30}$ Exhibit 2.3 summarizes responses to that inquiry. I found that working for tips plus the regular minimum wage is the most popular compensation system (with a net favorability of $+71 \%$ ), but working for tips plus a subminimum wage is one of the least popular compensation systems (with a net favorability of only $+1 \%$ ). Working for service charges (with an average net favorability of +19 ) and high hourly wages (with an average net favorability of +51 ) are both preferred to working for tips plus subminimum wages. These data suggest that abandoning tipping will lower employee satisfaction with the compensation system only in those states with no tip credit. For those states with tip credits, abandoning tipping may actually increase employee satisfaction with the compensation system, especially if tipping is replaced with high hourly wages.

Exhibit 2.3. Attitudes toward working for different types of compensation in a large and diverse, but unrepresentative, sample of the U.S. population

\begin{tabular}{|c|c|c|c|}
\hline Method of Compensation & Dislike $^{a}$ & Like $^{a}$ & $\begin{array}{l}\text { Net } \\
\text { Favorability } \\
\text { (Like minus } \\
\text { Dislike) }\end{array}$ \\
\hline $\begin{array}{l}\text { Tips with Subminimum Wage - } \\
\text { Servers make less than the regular minimum wage, but } \\
\text { keep the tips they receive }\end{array}$ & $44 \%$ & $45 \%$ & $+1 \%$ \\
\hline $\begin{array}{l}\text { Tips with Regular Minimum Wage - } \\
\text { Servers make the regular minimum wage and keep the } \\
\text { tips they receive }\end{array}$ & $9 \%$ & $80 \%$ & $+71 \%$ \\
\hline $\begin{array}{l}\text { Tip Pool with Subminimum Wage - } \\
\text { Servers make less than the regular minimum wage, but } \\
\text { receive a share of the tip pool that all tips go into }\end{array}$ & $69 \%$ & $23 \%$ & $-46 \%$ \\
\hline $\begin{array}{l}\text { Tip Pool with Regular Minimum Wage- } \\
\text { Servers make the regular minimum wage and a share of } \\
\text { the tip pool that all tips go into }\end{array}$ & $33 \%$ & $52 \%$ & $+19 \%$ \\
\hline $\begin{array}{l}15 \% \text { Service Charge (No Additional Tipping) - } \\
\text { Servers receive all the money from a } 15 \% \text { automatic } \\
\text { service charge to their customers and are not permitted } \\
\text { to accept tips }\end{array}$ & $34 \%$ & $49 \%$ & $+15 \%$ \\
\hline $\begin{array}{l}18 \% \text { Service Charge (No Additional Tipping) - } \\
\text { Servers receive all the money from an } 18 \% \text { automatic } \\
\text { service charge to their customers and are not permitted } \\
\text { to accept tips }\end{array}$ & $31 \%$ & $54 \%$ & $+23 \%$ \\
\hline $\begin{array}{l}\text { \$18/Hour Wage (No Additional Tipping) - } \\
\text { Servers make \$18 per hour and are not permitted to } \\
\text { accept tips }\end{array}$ & $20 \%$ & $70 \%$ & $+50 \%$ \\
\hline $\begin{array}{l}\text { \$21/Hour Wage (No Additional Tipping) - } \\
\text { Servers make \$21 per hour and are not permitted to } \\
\text { accept tips }\end{array}$ & $20 \%$ & $71 \%$ & $+51 \%$ \\
\hline
\end{tabular}


The attitudes summarized in Exhibit 2.3 reflect the opinions of a sample of the general U.S. population. Arguably, those attitudes are less important than the opinions of the best prospective restaurant employees, namely, those who have worked for tips, and who are outgoing and social (extraverted), emotionally stable (non-neurotic), friendly and easy going (agreeable), and dutiful, punctual, and hard-working (conscientious). If these selected groups of people have a strong preference for one particular method of compensation, then abandoning tipping may affect recruitment and retention of good servers even if the general population does not share that preference. To see whether the opinions of these select groups do differ from those of the general population, I regressed rated attitudes toward several of the compensation systems on a number of respondent characteristics measured in the survey (see Exhibit 2.4). Those analyses indicate that though there are some reliable differences in liking for specific compensation systems, the effects are small, and I conclude that the attitudes summarized in Exhibit 2.3 are held by many attractive prospective employees.

Exhibit 2.4. Attitudes toward working under different compensation systems do not vary much across respondents' personality and geo-demographic characteristics (standardized regression coefficients).

\begin{tabular}{|c|c|c|c|c|}
\hline \multirow{2}{*}{$\begin{array}{l}\text { Respondent } \\
\text { Characteristics } \\
\text { /Predictors }\end{array}$} & \multicolumn{4}{|c|}{ Attitude Toward Working for } \\
\hline & $\begin{array}{l}\text { Tips with Regular } \\
\text { Minimum Wage }\end{array}$ & $\begin{array}{l}\text { Tips with Sub- } \\
\text { Minimum Wage }\end{array}$ & $\begin{array}{l}18 \% \text { Service } \\
\text { Charges }\end{array}$ & $\begin{array}{l}\$ 18 \\
\text { Hourly } \\
\text { Wages }\end{array}$ \\
\hline Extraversion & .03 & $.11 * *$ & $-.08 *$ & -.06 \\
\hline Neuroticism & -.04 & -.04 & -.01 & -.01 \\
\hline Conscientiousness & .07 & .05 & -.03 & $-.10 *$ \\
\hline Agreeableness & .02 & .05 & .05 & $.07 *$ \\
\hline Openness & $.07 *$ & -.03 & .03 & .05 \\
\hline $\begin{array}{l}\text { Worked for Tips } \\
\text { Before }^{\mathrm{a}}\end{array}$ & .04 & .04 & -.02 & -.01 \\
\hline Age & .08 & .03 & .003 & $.08 *$ \\
\hline Female $^{\mathrm{a}}$ & .05 & -.03 & -.004 & .06 \\
\hline Education & $-.09 *$ & -.01 & -.01 & .01 \\
\hline Income & $-.09 *$ & -.01 & .06 & $-.09 *$ \\
\hline White $^{\mathrm{a}}$ & .03 & .01 & -.01 & -.02 \\
\hline Midwest $^{\mathrm{a}}$ & -.01 & $.10 *$ & -.06 & -.07 \\
\hline South $^{\mathrm{a}}$ & .03 & $.09 *$ & -.03 & -.01 \\
\hline West $^{\mathrm{a}}$ & -.03 & .02 & -.03 & .01 \\
\hline $\mathrm{R}^{2}$ & $.06 * * *$ & $.04 * *$ & .01 & $.05 * *$ \\
\hline $\mathrm{n}$ & 834 & 837 & 837 & 836 \\
\hline
\end{tabular}

Three other studies have examined the relationships of servers' average tip sizes or servers' attitudes toward working for tips with their service or guest 
orientation, years of waiting experience, job satisfaction, and intentions or thoughts about quitting. ${ }^{31}$ Their results are summarized in Exhibit 2.5. Overall, more experienced and service-oriented waiters and waitresses earn larger average tips and like working for tips more than do less experienced and service-oriented waiters and waitresses. Furthermore, servers who earn larger tips and prefer working for tips like their jobs more, think less about quitting, and intend to stay in the job longer. These findings are all consistent with the idea that tipping helps to attract and retain more experienced and service-oriented workers. However, the observed correlations are weak and the selective attraction and retention effects of tipping depend on linking these weak relationships together (see Exhibit 2.2), which means that those selective attraction and retention effects are of little consequence. ${ }^{32}$

Exhibit 2.5. Tip averages and attitude toward working for tips are only weakly related to desirable server characteristics (correlations).

\begin{tabular}{|c|c|c|}
\hline & Average Tip Size & $\begin{array}{l}\text { Prefer Working for Tips } \\
\text { (over Service Charges) }\end{array}$ \\
\hline Service/Guest Orientation & $\begin{array}{ll}.14^{\mathrm{a}} & (\mathrm{n}=130) \\
.18^{* * \mathrm{~b}} & (\mathrm{n}=334) \\
.06^{\mathrm{c}} & (\mathrm{n}=691)\end{array}$ & $\begin{array}{ll}.14^{* * \mathrm{~b}} & (\mathrm{n}=336) \\
.17^{* * *_{\mathrm{c}}} & (\mathrm{n}=693)\end{array}$ \\
\hline Years Experience as a Server & $\begin{array}{l}.26^{* * b}(\mathrm{n}=330) \\
.17^{* * *_{\mathrm{c}}}(\mathrm{n}=685)\end{array}$ & $\begin{array}{ll}.19^{* * \mathrm{~b}} & (\mathrm{n}=332) \\
.18^{* * \mathrm{c}} & (\mathrm{n}=687)\end{array}$ \\
\hline Job Satisfaction & $\begin{array}{l}.26^{* * a}(\mathrm{n}=130) \\
.24^{* * *_{\mathrm{c}}}(\mathrm{n}=689)\end{array}$ & $.32^{* *_{c}} \quad(\mathrm{n}=691)$ \\
\hline Intentions/Thoughts/Timing of Quitting & $\begin{array}{l}-.29^{* * a} \quad(n=130) \\
-.03^{c} \quad(n=692)\end{array}$ & $(n=694)$ \\
\hline
\end{tabular}

**p <.01, ${ }^{\mathrm{a}}$ from unpublished data collected by Alex Susskind and reported in Lynn (2003),

${ }^{\mathrm{b}}$ from Lynn, Kwortnik \& Sturman (2011), ${ }^{\mathrm{c}}$ from Lynn (2016b)

In summary, the available evidence suggests that the pay-premiums provided by tipping and its pay-for-performance nature do help attract and retain more desirable workers, but those effects are weak and do not justify the paypremiums that tipping gives servers.

\section{Does Tipping Increase (or Decrease) Customer Satisfaction with Service?}

As is the case with other issues connected with tipping, I see two opposing positions regarding tipping and customer satisfaction. One position is that tipping increases customer satisfaction in three ways. First, many consumers like tipping and the control it gives them, so the opportunity to tip is a positive feature of the service experience that may directly increase some customers' satisfaction. ${ }^{33}$ Second, most consumers believe that tipping motivates servers to provide better service, so it may increase consumer expectations of service, which would positively bias their perceptions of actual service and increase 
their satisfaction. ${ }^{34}$ Finally, tipping may increase actual service levels by motivating servers to deliver better service. ${ }^{35}$

The opposing position is that tipping decreases customer satisfaction in four ways. First, some consumers dislike tipping, so social pressures to tip are negative features of the service encounter that may directly decrease at least those customers' satisfaction. Second, tipping may undermine servers' intrinsic desires to serve their customers by focusing servers' attention on the immediate pursuit of money and the resulting inauthenticity of service may decrease customer satisfaction. Third, tipping may discourage teamwork among servers, which may decrease actual service levels and, with it, customer satisfaction. ${ }^{36}$ Finally, tipping may encourage discrimination in service delivery to consumers perceived to be poor tippers, which would decrease the satisfaction of those consumers. Let's consider the empirical evidence that addresses these opposing arguments.

\section{Do people like tipping?}

A number of online surveys have assessed consumers' attitudes toward tipping and its alternatives over the past several years (see Exhibit 3.1). ${ }^{37}$ Unfortunately, uncertainty about the sampling methods as well as variability in question wording and findings severely limit the usefulness of these surveys. For this reason, I asked respondents to my previously mentioned survey how much they (as consumers) liked or disliked a variety of different tipping policies in full-service restaurants. ${ }^{38}$ Their answers to those questions are summarized in Exhibit 3.2. Voluntary tipping is clearly the most liked policy (with a net favorability of 39\%), but service-inclusive menu pricing also has a net favorability (of about 17\%). Only automatic service charges are disliked by more people than like them. How well these attitudes generalize across geo-demographic segments was assessed in regression analyses summarized in Exhibit 3.3. Older respondents tended to like tipping more, and its alternatives less, than did younger respondents, but these differences were small, and few other reliable differences were observed. Thus, the results in Exhibit 3.2 are reasonably descriptive of the consumer attitudes that most restaurateurs in the U.S. are likely to face at the current time. 
Exhibit 3.1. Summary of recent tipping surveys.

\begin{tabular}{|c|c|c|c|}
\hline 2012 online survey & oogle Cons & er Surveys (n=1, & \\
\hline At restaurants, do y & refer to ha & ips/gratuity autor & tically add \\
\hline Yes & $12 \%$ & & \\
\hline & $42 \%$ & & \\
\hline Only for large group & $32 \%$ & & \\
\hline It depends & $14 \%$ & & \\
\hline 2013 online survey a & rveymonke & om $(n=500)$ & \\
\hline If given the choice $b$ & een tipping & uctures, which wo & d you prefe \\
\hline Current pricing struc & 8 & & \\
\hline Include gratuity into & $\begin{array}{l}u \text { prices } 1 \\
1\end{array}$ & & \\
\hline 2013 survey by Zaga & $=?)$ & & \\
\hline How would you feel & ut a no-tip & policy if it mean & igher ment \\
\hline Hate it & & $28 \%$ & \\
\hline Not sure & & $34 \%$ & \\
\hline Love it & & $21 \%$ & \\
\hline Like it but only in ups & restaurant & $17 \%$ & \\
\hline 2014 online survey & rip Adviso & $=3,700)$ & \\
\hline $\begin{array}{l}\text { Would it be better if } \\
\text { Yes } 33 \%\end{array}$ & s were incl & in the bill? (para & rased) \\
\hline 2014 online survey & sk Your T: & Market $(n=380$ & \\
\hline Do you think it shou & e mandato & or people to tip se & ers? \\
\hline Yes & & & $23 \%$ \\
\hline No, but people shoulc & most of the & & $48 \%$ \\
\hline No, tipping should be & erved for ex & tional service & $16 \%$ \\
\hline No, service charges s & ld just be in & led in food prices & $9 \%$ \\
\hline No opinion & 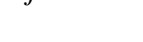 & r 1 & $3 \%$ \\
\hline $\begin{array}{l}2015 \text { online survey } b \\
(n=535)\end{array}$ & YC Hospit & y Alliance and $\mathrm{Au}$ & ence Resea \\
\hline I think tipping is a $\mathrm{g}$ & system & & \\
\hline Agree & & $53 \%$ & \\
\hline Disagree & & $24 \%$ & \\
\hline Neither & & $23 \%$ & \\
\hline Preferred way of ha & ng tipping & asual/family-style & estaurants \\
\hline Cash & & $31 \%$ & \\
\hline Credit card & & $40 \%$ & \\
\hline Administrative fee of & b to $20 \%$ & $18 \%$ & \\
\hline Increase menu prices & $\%$ to $20 \%$ & $11 \%$ & \\
\hline Preferred way of ha & ng tipping & ine dining establi & nents \\
\hline Cash & & $37 \%$ & \\
\hline Credit card & & $29 \%$ & \\
\hline Administrative fee of & b to $20 \%$ & $22 \%$ & \\
\hline Increase menu prices & $\%$ to $20 \%$ & $12 \%$ & \\
\hline
\end{tabular}


Exhibit 3.2. Consumer attitudes toward tipping and alternative policies at fullservice restaurants among a large and heterogeneous, but unrepresentative, sample of the U.S. population.

\begin{tabular}{lccl}
\hline Tipping Policy & Dislike & Like $^{\mathrm{a}}$ & $\begin{array}{l}\text { Net Favorability } \\
\text { (Like minus Dislike) }\end{array}$ \\
\hline $\begin{array}{l}\text { Tipping is Voluntary but Expected } \\
\text { (as per current custom) }\end{array}$ & $24 \%$ & $63 \%$ & $+39 \%$ \\
$\begin{array}{l}\text { Automatic Service Charges are added to } \\
\text { all checks (additional tipping is permitted } \\
\text { but not expected) }\end{array}$ & $52 \%$ & $35 \%$ & $-17 \%$ \\
$\begin{array}{l}\text { Automatic Service Charges are added to } \\
\text { all checks (additional tipping is not } \\
\text { permitted) }\end{array}$ & $50 \%$ & $38 \%$ & $-12 \%$ \\
$\begin{array}{l}\text { Higher Menu Prices include full } \\
\text { compensation for servers (tipping is } \\
\text { permitted but not expected) }\end{array}$ & $35 \%$ & $51 \%$ & $+16 \%$ \\
$\begin{array}{l}\text { Higher Menu Prices include full } \\
\text { compensation for servers (tipping is not } \\
\text { permitted) }\end{array}$ & $35 \%$ & $53 \%$ & $+18 \%$ \\
$\begin{array}{l}\text { a Collapsing across three levels each of like and dislike from ratings on a seven point scale } \\
\text { ranging from 1 = strongly dislike to } 7 \text { = strongly like. }\end{array}$ &
\end{tabular}

Exhibit 3.3. Consumer attitudes toward different tipping policies do not vary much across their geo-demographic characteristics (standardized regression coefficients).

Consumer Attitude Toward Policy of

Characteristics/

Predictors

\begin{tabular}{|c|c|c|c|c|c|}
\hline & $\begin{array}{l}\text { Tips } \\
\text { Expected }\end{array}$ & $\begin{array}{l}\text { Service } \\
\text { Charge } \\
\text { Plus }^{\mathrm{a}}\end{array}$ & $\begin{array}{l}\text { Service } \\
\text { Charge } \\
\text { Onlyb }\end{array}$ & $\begin{array}{l}\text { Service- } \\
\text { Inclusive } \\
\text { Menu Pricing } \\
\text { Plus }^{\mathrm{a}}\end{array}$ & $\begin{array}{l}\text { Service- } \\
\text { Inclusive } \\
\text { Menu } \\
\text { Pricing } \\
\text { Onlyb } \\
\end{array}$ \\
\hline Age & $.07 *$ & $-.10 * *$ & $-.11 * *$ & $-.11 * *$ & $-.07 *$ \\
\hline Female $^{\mathrm{c}}$ & $.07 *$ & .02 & .002 & .06 & .03 \\
\hline Education & -.01 & .03 & .05 & .04 & $.10 * *$ \\
\hline Income & .04 & -.004 & -.003 & -.04 & -.03 \\
\hline White ${ }^{c}$ & -.002 & -.03 & $-.07 *$ & -.02 & -.01 \\
\hline Midwest $^{\mathrm{c}}$ & .03 & .01 & -.01 & -.002 & -.03 \\
\hline South $^{c}$ & .05 & $.09 *$ & .04 & .04 & .01 \\
\hline West $^{\mathrm{c}}$ & -.01 & .02 & -.03 & .03 & -.02 \\
\hline Worked for Tips ${ }^{c}$ & .03 & -.05 & $-.07 *$ & $-.08 *$ & $-.11 * *$ \\
\hline $\mathrm{R}^{2}$ & .02 & $.02 *$ & $.03 * *$ & $.03 * *$ &. $\mathbf{0 3} * *$ \\
\hline $\mathrm{n}$ & 844 & 844 & 842 & 844 & 844 \\
\hline
\end{tabular}

$* \mathrm{p}<.05,{ }^{* *} \mathrm{p}<.01,{ }^{* * *} \mathrm{p}<.001,{ }^{\mathrm{a}}$ Tipping is permitted but not expected., ${ }^{\mathrm{b}}$ Tipping is not permitted. ${ }^{\mathrm{c}}$ yes $=1$, no $=0$

To get a sense of whether these attitudes toward different tipping policies would affect patronage of restaurants adopting the different policies, Shuo Wang and I conducted three experiments that speak to this issue. ${ }^{39}$ These experiments presented large and diverse samples of the U.S. population a 
restaurant menu or flyer that contained information about the restaurant's tipping policy, which was randomly varied across respondents, and asked them to rate the fairness of those policies and the likelihood of going to the restaurant (among other things). All three studies found that automatic gratuities were perceived as less fair than voluntary tipping policies and that the lower perceived fairness of automatic gratuities reduced the average rated likelihood of going to the restaurant by .2 to .4 out of 7 points. One of the studies also included a no-tipping, service-inclusive menu pricing policy and found that the lower perceived fairness of that policy compared to voluntary tipping reduced the average rated likelihood of going to the restaurant by .2 out of 7 points. ${ }^{40}$ These findings suggest that attitudes toward tipping policies are likely to affect patronage intentions, but only to a small degree.

\section{Does tipping increase consumer expectations of service quality?}

Surveys have found that most consumers believe that they tip based on the service they receive and, therefore, that tipping motivates servers to deliver good service. ${ }^{41}$ This suggests that tipping is likely to increase consumers' expectations of service quality and that abandoning tipping might lower their service expectations. This possibility is important because expectations influence both consumer choices and consumer experiences. If tipping does increase consumer expectations of service quality, then consumers may be less likely to try a no-tipping restaurant and may have a negatively biased perception of those no-tipping restaurants they do try.

One of my experiments with Shuo Wang tested the effects of tipping policies on expectations of service. ${ }^{42}$ The respondents' expectations of service quality where unaffected by whether they believed the restaurant had an automatic gratuity or a voluntary tipping policy. This surprising finding needs to be replicated, but if it is reliable, it suggests that replacing tipping with automatic service charges may not lower expectations about a restaurant's service quality. On the other hand, study respondents did rate the expected service quality half a point lower out of 7 points when they believed the restaurant had a service-inclusive menu pricing policy than when they believed it had a voluntary tipping policy. Although this effect in turn lowered the average rated likelihood of patronage by only .1 out of 7 points, a half-point difference in average ratings of expected service levels is not trivial. ${ }^{43}$ Thus, restaurants contemplating replacing tipping with serviceinclusive menu prices should consider this cost and ways to mitigate it. Presumably fancier menu items, more varied wine selections, higher prices, classier employee uniforms, nicer table wear and décor, and other cues associated with upscale, fine-dining establishments could all be used to create high service expectations even in the absence of voluntary tipping. ${ }^{44}$ 
Does tipping motivate servers to deliver better service?

Tipping is supposed to be an incentive and reward for good service, but the jury is still out on how much it really motivates servers to deliver better service. Early research found that tip sizes were only weakly related to customers' ratings of service quality, leading me to doubt tipping's value as an incentive for better service. ${ }^{45}$ However, more recent research has led me to modify that conclusion. Three surveys of restaurant waiters and waitresses indicate that many servers mistakenly believe the relationship between tips and service is strong. ${ }^{46}$ For example, the most recent of these surveys asked almost 700 restaurant servers from across the U.S. to rate how large an effect the quality of their service has on the size of tips they receive, using a sevenpoint scale. ${ }^{47}$ Seventy percent of the respondents rated the service-tipping relationship above the mid-point on this scale (see Exhibit 3.4), indicating that they thought their service had moderately to large effects on their tips. Perhaps servers need to have these inaccurate perceptions, because the perceptions contribute to servers' feelings of control and reduce servers' feelings that they depend on charity.

Exhibit 3.4. Despite the weak actual service-tipping relationship, restaurant servers believe that delivering better service results in larger tips.

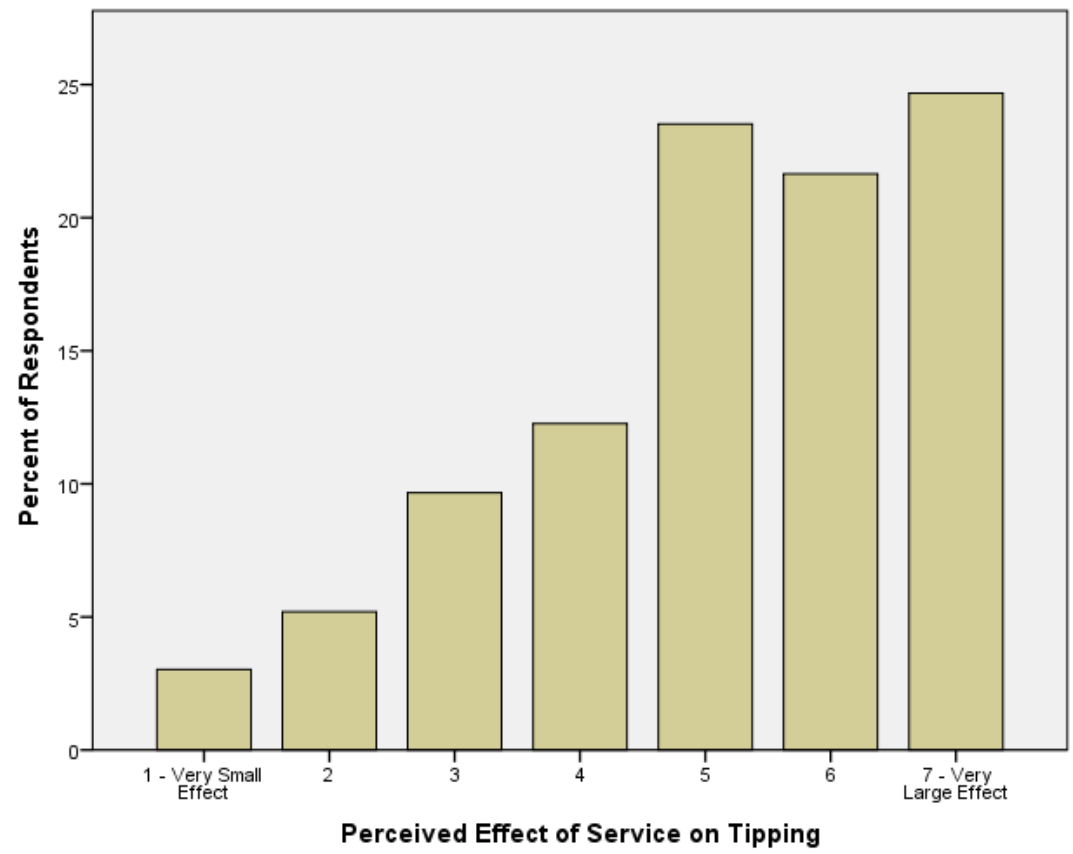

Regardless of how they are developed and maintained, servers' beliefs that tips are strongly related to service suggests that tipping does motivate servers to provide better service. Further supporting this conclusion are two studies I 
conducted with Rob Kwortnik and Bill Ross. ${ }^{48}$ In one study, 469 current or former servers read a scenario describing a restaurant and indicated (with 7point scales) how often they would engage in various customer- and salesoriented behaviors if they worked as a server in that restaurant. The customeroriented behaviors included checking up on the table, complimenting customers' food choices, and thanking customers while the sales-oriented behaviors included recommending branded and high price selections and speeding up service to turn the table. The scenario was randomly varied to present respondents with one of three tipping policies: voluntary tipping, an automatic gratuity, or no tipping with high wages. The results are depicted in Exhibit 3.5. Customer-oriented behavior was highest under a voluntary tipping policy $($ mean $=4.9)$, intermediate under an automatic gratuity policy $($ mean $=4.4)$, and lowest under a wages-only policy (mean $=3.9$ ), with all of these differences being statistically reliable. Sales-oriented behavior was significantly higher under both voluntary tipping (mean $=4.8$ ) and automatic gratuity policies (mean $=5.1$ ), which did not reliably differ from one another, than under a wages-only policy (mean $=2.9$ ). These findings suggest that replacing tipping with automatic service charges will reduce customer-oriented, though not sales-oriented, behaviors and that replacing tipping with wages only will reduce both customer- and sales-oriented behaviors.

Exhibit 3.5. Hypothetical sales- and customer-oriented behavior is lower under a wages only policy than a voluntary tipping policy and customer-oriented (but not sales-oriented) behavior is lower under a service charge policy than voluntary tipping policy.

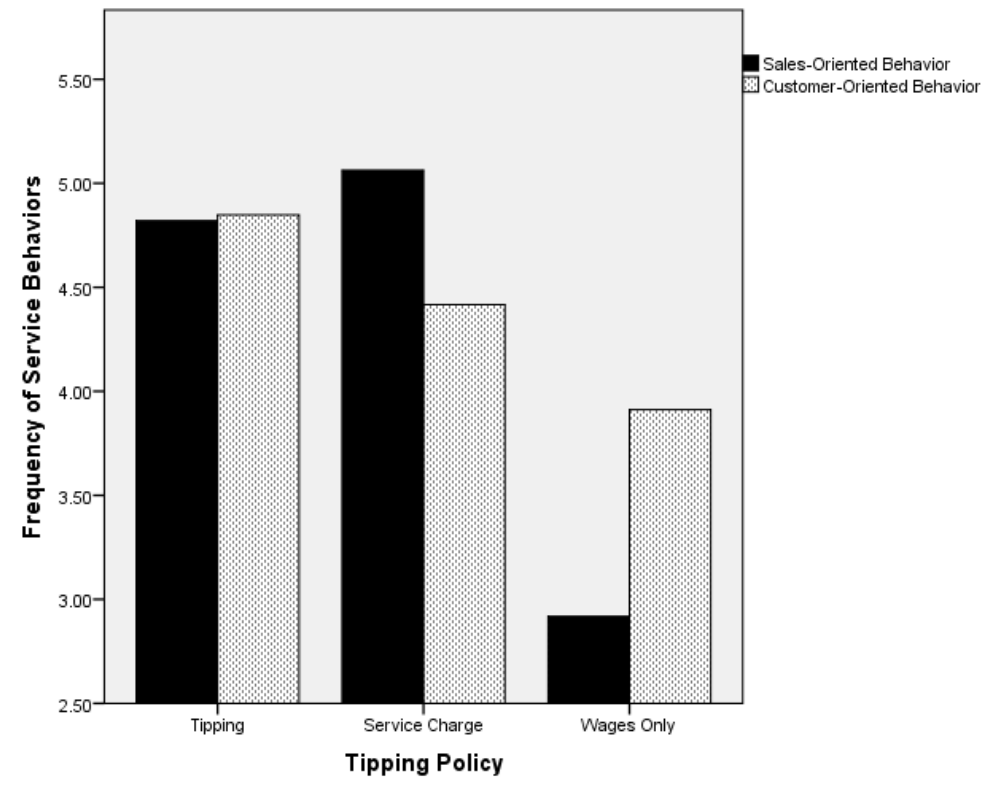


In a second study, we asked over a thousand restaurant servers in the U.S. to indicate how often they engaged in nine positive service behaviors (such as introducing themselves by name, smiling at customers, and complimenting customers' food choices) and how large an effect they thought their service had on their tips. Consistent with a motivational effect of tipping, we found that the likelihood that servers would engage in the positive service behaviors increased with their belief about how strongly service affects tip size ( $\mathrm{r}=$ $.17, \mathrm{n}=1171, \mathrm{p}<.001)$. Note that this effect was not nearly as large or strong as those in the hypothetical scenario experiment described above. That could be because the hypothetical scenario experiment overstated the strength of the effects that can be expected on actual behavior. However, it is also possible that the comparison of service across different levels of perceived service-tip contingency understates the motivational effects of tipping because servers find the prospect of earning even slightly larger tips more motivating than working for a set service charge or wage.

\section{Does tipping reduce service authenticity?}

Psychological research has found that extrinsic rewards (such as tips) reduce intrinsic motivation. ${ }^{49}$ To the extent that intrinsically motivated behavior comes across as more authentic than extrinsically motivated behavior, tipping may decrease the perceived authenticity of service. Such an effect would be undesirable, because researchers have found that consumers are able to distinguish authentic emotional labor from feigned emotional displays and prefer the former to the latter. ${ }^{50}$ Consistent with this concern about tipping reducing servers' intrinsic motivation, Catherine Curtis and colleagues found that tipped restaurant workers rated two intrinsic work motivations - the importance of interesting work and gratitude for a job well done - as less important than did their non-tipped co-workers. ${ }^{51}$ However, Curtis's study involved a small sample, many comparisons, and weak effects, so her findings may be false positives (Type 1 errors). In addition, her comparison of tipped with non-tipped workers' motivation confounded tipping with other job characteristics, so it is not clear that tipping produced the differences she observed even if they are reliable.

Arguing against the idea that tipping reduces intrinsic motivation are several studies indicating that servers (correctly) believe that a variety of tipenhancing tactics give them control over their tip income. ${ }^{52}$ Perceptions of empowerment and control have been shown to mitigate and even reverse the negative effects of extrinsic rewards on intrinsic motivation. ${ }^{53}$ Thus, by enhancing servers' perceptions of control over their incomes, tipping may actually increase (rather than decrease) servers' intrinsic motivation and the authenticity of service. 
Does tipping motivate service discrimination?

Although tipping generally enhances servers' motivation to deliver good service, many people argue that it has the opposite effect on servers' motivation to serve groups that are perceived to be poor tippers. Indeed, there is a growing body of both qualitative and quantitative research documenting the effects of expecting low tips on service discrimination against foreigners, ethnic minorities, and others. ${ }^{54}$ Some indication of how pervasive such tipping-based service discrimination is likely to be can be found in the responses to two additional survey questions in the 700 -server study that I discussed above. ${ }^{55}$

One question asked the servers to rate a number of different consumer groups on a scale of "very bad" to "very good" tippers. As depicted in Exhibit 3.6, foreigners, teenagers, coupon users, Blacks, Hispanics, Christians, and the elderly are all widely perceived to be below-average tippers. Again, the sample was not representative, but regression analyses indicated that servers' perceptions of various groups' tipping behavior did not vary much across servers' geo-demographic and workplace characteristics (see Exhibit 3.7). Thus, these perceptions are held by a wide range of restaurant servers. ${ }^{56}$

Exhibit 3.6. Average perceptions of the tipping of various consumer groups by U.S. waiters and waitresses. Idea for graphic from Tim Urban at http://waitbutwhy.com/ 2014/04/everything-dont-know-tipping.html.

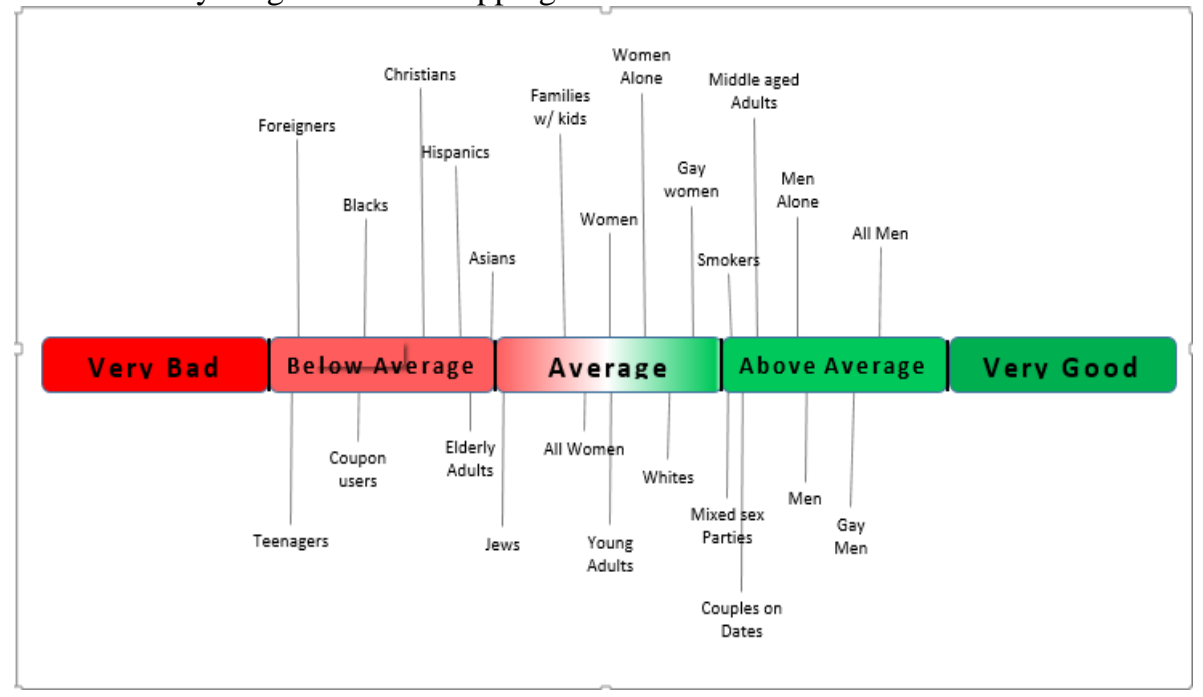


Exhibit 3.7. Servers' perceptions of various groups' tipping behavior do not vary much across servers' geo-demographic and workplace characteristics (standardized regression coefficients).

\begin{tabular}{|c|c|c|c|c|c|c|c|}
\hline \multirow{2}{*}{$\begin{array}{l}\text { Server Charac- } \\
\text { teristics/ } \\
\text { Predictors }\end{array}$} & \multicolumn{7}{|c|}{ Perceptions of Group as Good Tippers } \\
\hline & $\begin{array}{l}\text { Foreign- } \\
\text { ers }\end{array}$ & $\begin{array}{l}\text { Teen- } \\
\text { agers }\end{array}$ & $\begin{array}{l}\text { Coupon } \\
\text { Users }\end{array}$ & Blacks & $\begin{array}{l}\text { His- } \\
\text { panics }\end{array}$ & $\begin{array}{l}\text { Chris- } \\
\text { tians }\end{array}$ & Elderly \\
\hline Age & -.04 & $.11 *$ & .05 & $.11 *$ & .06 & -.003 & $.14 * *$ \\
\hline Female $^{a}$ & $.08^{*}$ & -.04 & .02 & .01 & -.01 & .01 & .06 \\
\hline White $^{\mathrm{a}}$ & -.02 & -.01 & -.08 & -.03 & .01 & .02 & -.07 \\
\hline Married $^{\mathrm{a}}$ & -.02 & -.02 & -.05 & -.01 & .05 & .03 & -.03 \\
\hline Midwest ${ }^{\mathrm{b}}$ & .06 & .03 & -.08 & -.07 & .10 & -.06 & -.04 \\
\hline South ${ }^{\mathrm{b}}$ & .10 & -.03 & -.05 & -.06 & .08 & $-.15 *$ & -.06 \\
\hline West $^{\mathrm{b}}$ & .09 & $-.10 *$ & -.04 & .08 & -.02 & .001 & -.03 \\
\hline $\begin{array}{l}\text { Inexpensive } \\
\text { Restaurant }^{\mathrm{a}}\end{array}$ & .01 & -.01 & .02 & .08 & .01 & .01 & -.07 \\
\hline $\begin{array}{l}\text { Moderately } \\
\text { Expensive } \\
\text { Restaurant }^{\mathrm{a}}\end{array}$ & -.08 & -.04 & .01 & -.01 & -.08 & -.04 & -.08 \\
\hline $\begin{array}{l}\text { Suburban } \\
\text { Restaurant }^{\mathrm{a}}\end{array}$ & -.03 & -.01 & .02 & -.04 & -.01 & .03 & .06 \\
\hline $\begin{array}{l}\text { Urban } \\
\text { Restaurant }^{\mathrm{a}}\end{array}$ & -.08 & -.04 & -.03 & -.06 & -.07 & .10 & .10 \\
\hline $\begin{array}{l}\text { Lots of foreign } \\
\text { customers }\end{array}$ & $-.13 * *$ & -.03 & -.05 & .01 & .03 & -.08 & -.04 \\
\hline $\begin{array}{l}\text { Lots of ethnic } \\
\text { minority } \\
\text { customers }^{\mathrm{a}}\end{array}$ & .02 & -.03 & .02 & $-17 * * *$ & $-.15 * *$ & .01 & -.003 \\
\hline $\begin{array}{l}\text { Lots of } \\
\text { elderly/retired } \\
\text { customers }{ }^{\text {a }}\end{array}$ & .06 & .07 & -.03 & -.01 & .08 & .003 & .02 \\
\hline $\mathrm{R}^{2}$ & $.06^{* *}$ & .04 & .02 & $.08 * * *$ & $.05 *$ & .03 & .04 \\
\hline $\mathrm{N}$ & 603 & 624 & 572 & 595 & 568 & 479 & 629 \\
\hline
\end{tabular}

The second question asked servers how often they had given substandard service to customers expected to be poor tippers. Thirty-eight percent of the servers acknowledged at least sometimes doing so (see Exhibit 3.8). This tendency to give substandard service to customers perceived to be poor tippers did not vary much across servers' geo-demographic and workplace characteristics, but was greater for servers who were younger, lived in the northeast (especially compared to the south), and had lots of ethnic minority customers (see Exhibit 3.9). Overall, if servers' self-reports are to be believed, tipping motivated service discrimination is not common, but is not rare either. Since this service discrimination is most likely to be directed at foreigners, teenagers, coupon users, Blacks, Hispanics, Christians and the elderly, restaurateurs with a large proportion of one or more of these groups in their customer base may find that abandoning tipping improves their restaurants' overall service evaluations. 
Exhibit 3.8. Thirty-eight percent of U.S. servers admit that they sometimes (or more often) give substandard service to customers expected to be poor tippers.

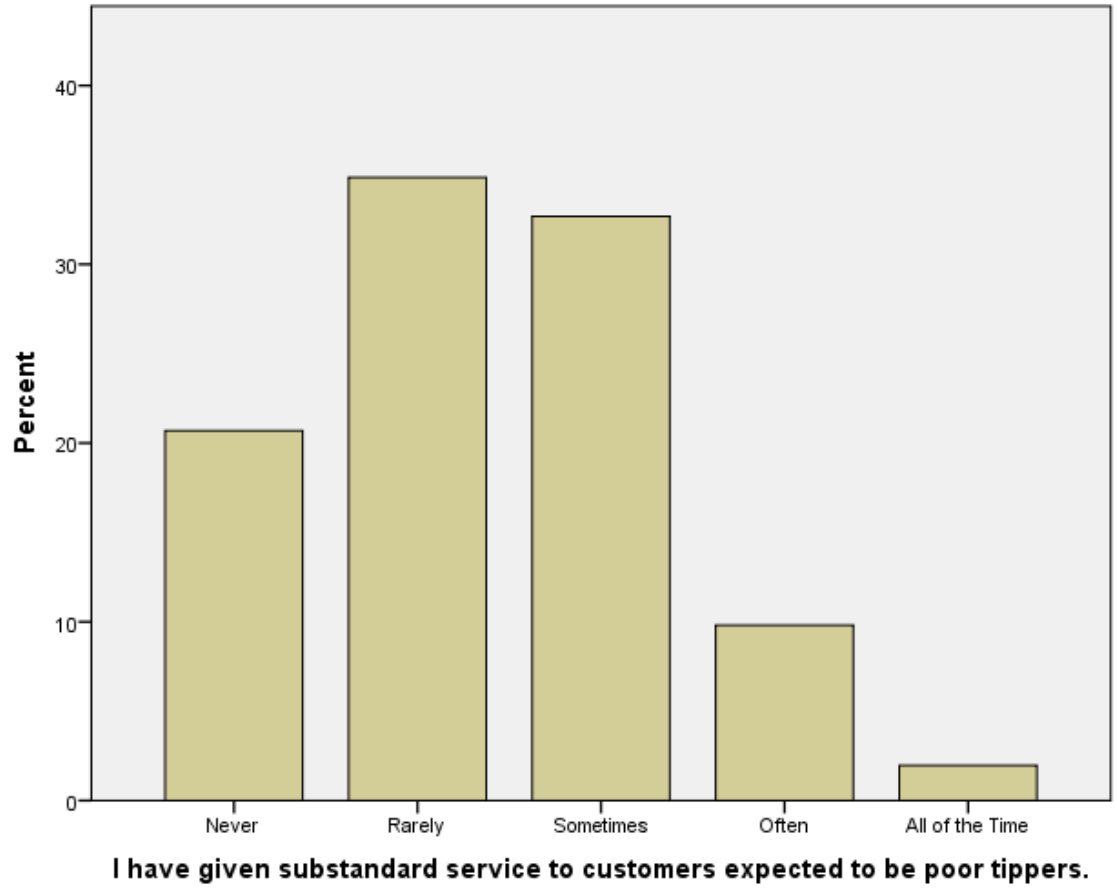

Exhibit 3.9. Servers' tendencies to give substandard service to customers perceived to be poor tippers do not vary much across servers' geo-demographic and workplace characteristics, but are greater for servers who are younger, male, live in the northeast (especially compared to the south), and have lots of ethnic minority customers (standardized regression coefficients).

\begin{tabular}{|c|c|}
\hline Server Characteristics/Predictors & Frequency of Substandard Service to Poor Tippers \\
\hline Age & $-.23 * * * *$ \\
\hline Female $^{a}$ & $-.09 *$ \\
\hline White $^{\mathrm{a}}$ & -.03 \\
\hline Married $^{\mathrm{a}}$ & .02 \\
\hline Midwest ${ }^{\mathrm{b}}$ & -.07 \\
\hline South $^{\mathrm{b}}$ & $-.10 *$ \\
\hline West $^{\mathrm{b}}$ & -.04 \\
\hline Inexpensive restaurant ${ }^{\mathrm{a}}$ & .01 \\
\hline Moderately expensive restaurant ${ }^{\mathrm{a}}$ & -.03 \\
\hline Suburban restaurant ${ }^{\mathrm{a}}$ & .01 \\
\hline Urban restaurant $^{\mathrm{a}}$ & -.05 \\
\hline Lots of foreign customers ${ }^{\mathrm{a}}$ & -.04 \\
\hline Lots of ethnic minority customers ${ }^{\mathrm{a}}$ & .13 ** \\
\hline Lots of elderly/retired customers a & -.03 \\
\hline $\mathrm{R}^{2}$ & $.08 * * *$ \\
\hline $\mathrm{N}$ & 629 \\
\hline
\end{tabular}


Does tipping reduce teamwork among servers?

Although tipping may motivate servers to take care of their own customers, some people argue that it lowers overall service quality by discouraging cooperative teamwork among servers. ${ }^{57}$ Empirical comparisons of server team work in tipped and non-tipped restaurants is not available, but Rachel Barkan and her colleagues have compared server competitiveness in individual-tip vs pooled-tip cafés in Israel. ${ }^{58}$ In one study, they found that server competitiveness is greater in cafés with individual tips than where tips are pooled. A follow-up study found that differences in service levels between individualtip and pooled-tip cafes depended on how visible servers' efforts were to one another. Among cafés with large open spaces where servers could observe one another (and, therefore, punish slackers), service was faster and more problem-free under the pooled-tip system. However, among cafés with multiple separate dining spaces where servers could not observe one another, service was faster and more problem-free under the individual-tip system. These findings suggest that abandoning individual tipping will improve teamwork, but will also increase server slacking unless mechanisms are in place to detect and punish slackers. That may be why another researcher, Samuel Zakay, found that Zagat service ratings of 74 restaurants in NYC were unaffected by whether the restaurants pooled tips. ${ }^{59}$ Three studies is not much to go on and more research on this topic is needed, but the available evidence suggests that improvements in teamwork brought about by abandoning tipping will not routinely outweigh the resulting loss in individual server motivation.

\section{What are the net effects of tipping on customer satisfaction?}

Weighing the evidence described above, I believe that the positive effects appear to be better established, stronger, and more generalizable than the negative effects. Thus, I believe that tipping has a net positive effect on customer satisfaction in most settings. Three studies by Rob Kwortnik and I directly support this belief. ${ }^{60}$ One study found that consumers' online reviews of Carnival cruises were higher before the cruise line replaced voluntary tipping with automatic service charges than afterwards (average ratings $=4.0$ vs. 3.7, $\mathrm{t}(1117)=1.77$, one-tailed $\mathrm{p}<.04)$. A second study found that service ratings in 1995 were higher for 54 cruise ships with voluntary tipping than for 16 ships with no tipping (average ratings $=7.45$ vs. $7.05, \mathrm{~F}(1,61)=$ $5.84, \mathrm{p}<.02$ ), after statistically controlling for the ratio of passengers to crew, passenger space ratio, ship dress code, and price tier. The final study found that Miami Beach restaurants with voluntary tipping had higher Zagat service ratings than did those with service charges (average ratings $=19.5 \mathrm{vs}$ $18.5, \mathrm{t}(102)=2.62, \mathrm{p}<05)$, after controlling for food, décor, and cost ratings. The sizes of these effects were modest -0.3 out of 5 points, 0.4 out 
of 10 points, and 1.0 out of 33 points - and many non-tipping establishments received high ratings, so tipping is not necessary to satisfy guests, but it does appear to help.

\section{Does Tipping Increase Demand by Reducing the Costs of Eating Out or Perceptions of Restaurant Expensiveness?}

Many restaurateurs fear that replacing tipping with either service charges or higher service-inclusive menu prices will increase the actual or perceived expensiveness of their restaurants and, thereby, reduce sales. The available evidence supports these fears, as explained below.

How many substandard tippers would face price increases if tipping were abandoned?

The voluntary nature of tipping means that people can limit their payment for the service component of the restaurant dining experience to an amount as low as they want. The hope is that extremely low tips from price-sensitive customers will be made up for with larger tips from price-insensitive customers. In essence, tipping enables wealthy and price-insensitive customers to subsidize the dining experiences of poor and price-sensitive customers. ${ }^{61}$ Eliminating tipping and forcing everyone to pay the same amount for service removes this subsidy, which is likely to decrease demand from restaurants' poorer and more price-sensitive customers.

To get some sense of the magnitude of this threat, I used April 2013 charge sales and tip data from seven restaurant chains (provided by NCR) and calculated the proportion of customers who would be forced to pay more under systems that replaced tipping with menu price increases or service charges of 15 percent, 18 percent, or 20 percent. Collectively, the restaurant chains operated in 48 states (and the District of Columbia) and spanned a wide range of price-tiers, with median check sizes ranging from $\$ 13$ to $\$ 135$. Overall, 24 percent of the restaurant's patrons tipped less than 15 percent of the bill, 46 percent of them tipped less than 18 percent of the bill, and 66 percent of them tipped less than 20 percent of the bill. These percentages varied only a little with restaurant price-tier (see Exhibit 4.1). They also varied a little across states, with the Northeast having fewer substandard tippers (see Exhibit 4.2). Nevertheless, the data suggest that almost all restaurants replacing tipping with service charge or service-inclusive menu pricing systems would raise prices on a substantial proportion of their customers, and to the extent that those customers are price sensitive, would see some decrease in sales and profits. 
Exhibit 4.1. Across a wide range of restaurant price-tiers, roughly 25, 45 and 65 percent of restaurant customers tip less than $15 \%, 18 \%$ and $20 \%$ of the bill respectively and would face higher prices under corresponding service charges or higher service-inclusive prices.

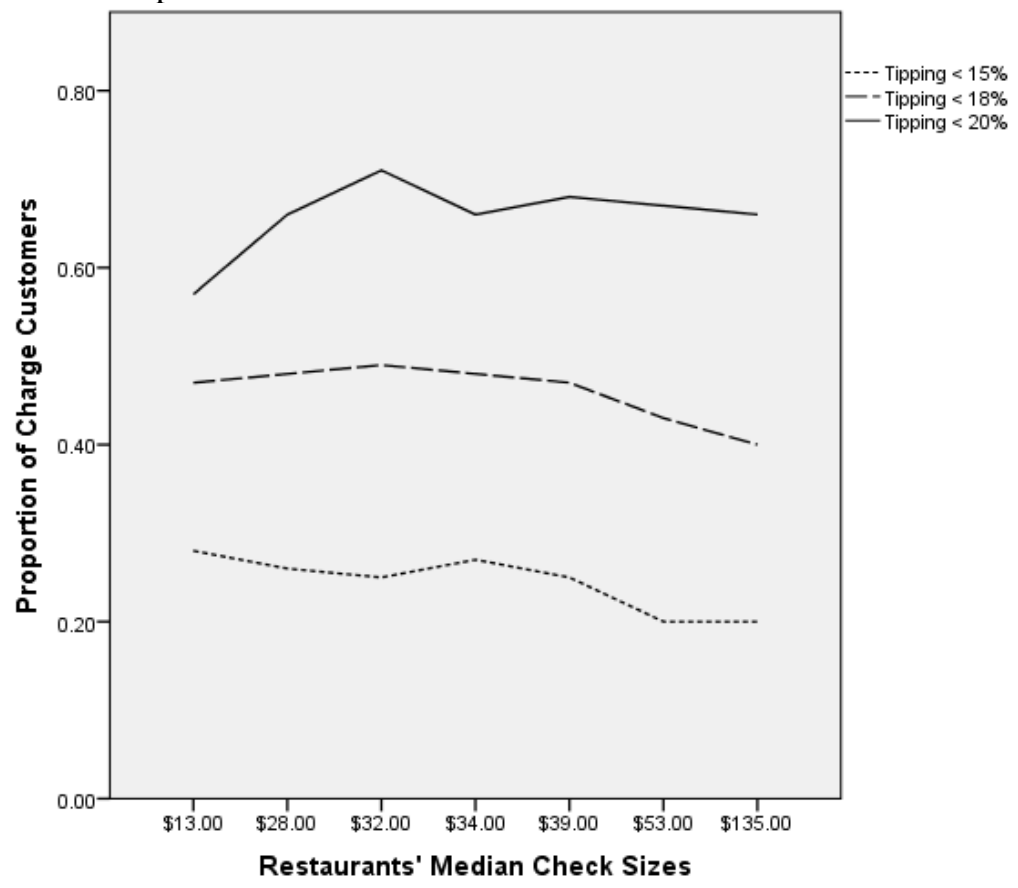

Exhibit 4.2. The proportion of customers tipping less than 15 percent varies a little across states with the fewest bad tippers living in the North Eastern United States (based on charge data from a national restaurant chain whose median bill size is $\$ 34$ ).

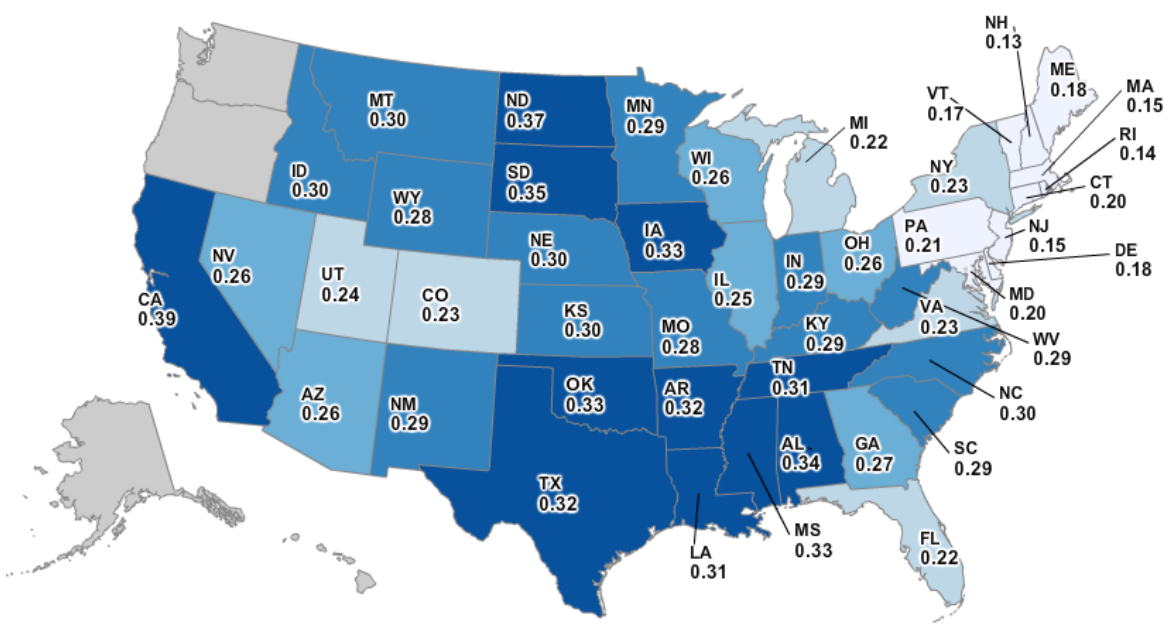


How would the price increases associated with abandoning tipping affect restaurant sales?

While it is hard to say precisely what effect changes in menu prices would have on restaurant sales, I can make an estimate based on existing data. Two recent econometric studies of consumer expenditures on food away from home indicate that a 1-percent increase in prices reduces expenditures at sitdown or full-service restaurants by 1.3 to 2.0 percent. ${ }^{62} \mathrm{~A}$ third study found that a 1-percent increase in prices reduces consumer expenditures by .92 percent at casual restaurants, .79 at mid-range restaurants, and .58 at fine dining restaurants. ${ }^{63}$ These numbers suggest that a 15 -percent hike in restaurant prices will reduce sales by anywhere from 9 to 30 percent! Of course, replacing tipping with a 15 -percent service charge or with 15 -percent higher menu prices does not increase the cost of dining by 15 percent, because those price increases are offset by the fact that patrons no longer have to tip. However, it would increase costs somewhat for the roughly 25 percent of customers who tip less than 15 percent of the bill. The mean tip left by sub15-percent tippers is roughly 12 percent of the bill in the restaurant samples described above. A 15-percent service charge or price hike would raise those people's costs of eating out by about 3 percentage points, which would reduce their demand by 1.7 to 6 percent. Since they represent roughly a quarter of all restaurant patrons, overall demand would decline by about .5 to 1.5 percent assuming no other changes.

Of course, many big tippers would pay less under no-tipping systems. While one might expect that this would increase their demand for restaurant services, any such effect is likely to be small. A survey I did a few years back found that consumers' sensitivity to restaurant prices was negatively related to the amounts they tipped ( $\mathrm{r}$ with cash tip $=-.21, \mathrm{n}=160, \mathrm{p}<.008 ; \mathrm{r}$ with percent tip $=-.14, \mathrm{n}=493, \mathrm{p}<.003$; see Exhibit 4.3). ${ }^{64}$ This means that big tippers are less responsive to restaurant price changes than are small tippers. Furthermore, other research has found that all consumers tend to be more sensitive to price increases than to price decreases. ${ }^{65}$ These findings suggest that any positive effects of eliminating tipping on the demand of big tippers will be too small to fully offset its negative effects on the demand of small tippers. 
Exhibit 4.3. Big tippers are less sensitive to restaurant prices than are small tippers, so eliminating tipping will reduce demand from small tippers more than it will increase demand from big tippers.

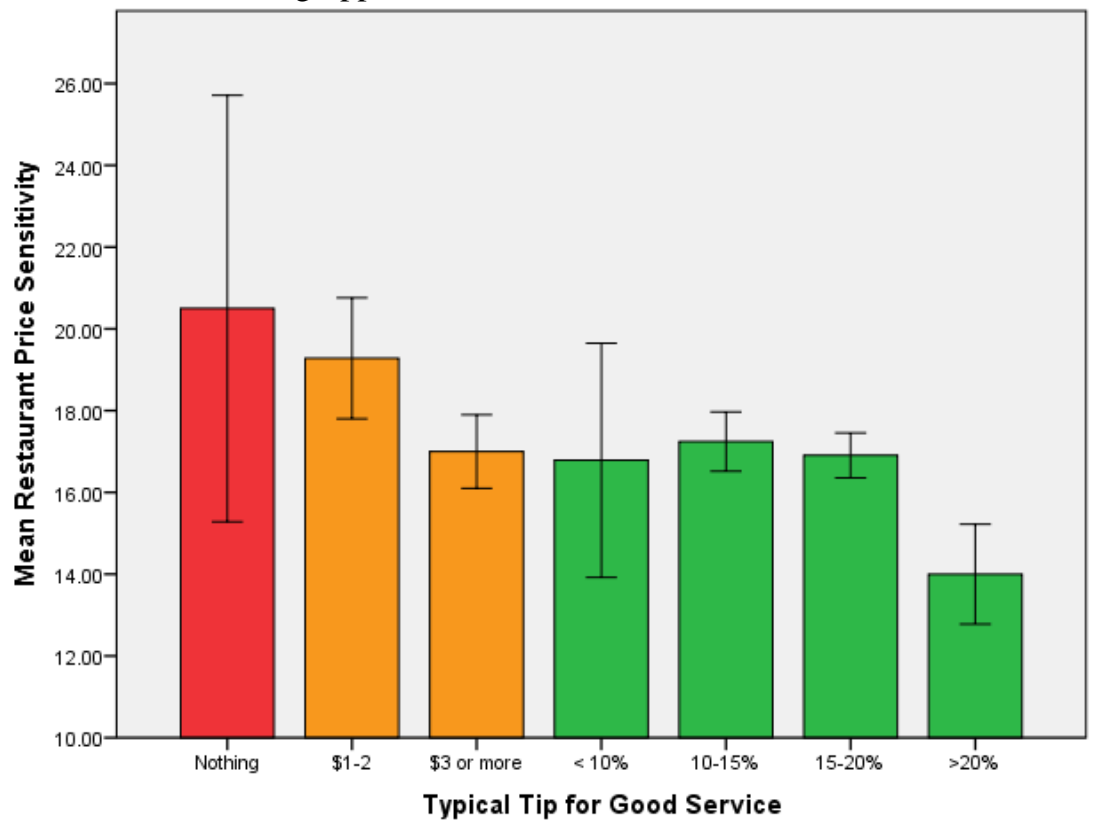

Error Bars: $95 \% \mathrm{Cl}$

Are non-tipping restaurants perceived as more expensive than tipping ones when the total costs of each are similar?

Even if actual total costs to consumers are unaffected, there are reasons to believe that replacing tipping with either higher service-inclusive menu prices or automatic service charges will increase perceptions of restaurant expensiveness and, thereby, reduce demand. The reasons for this effect differ for service-inclusive menu prices and service charges. Service-inclusive menu prices present customers with one consolidated price, while voluntary tipping and service charges present them with separate prices for the food and service components of the dining experience. Marketing researchers have found that presenting separate prices for each component in a bundle of components (as opposed to presenting one total price) often reduces perceptions of expensiveness. This occurs because consumers tend to focus on the more salient or expensive component's price and fail to fully process or integrate the other components' prices. ${ }^{66}$ If this pattern holds with consumers' evaluations of restaurant expensiveness, then consumers will focus on menu prices and perceive restaurants with no-tipping and higher, service-inclusive menu prices as more expensive than restaurants with voluntary tips or service charges that are offset with lower prices. 
As just mentioned, automatically adding service charges presents customers with separate prices for the food and service components of the dining experience, so it should not increase perceptions of restaurant expensiveness in the same way or to the same extent that service-inclusive menu pricing does. However, the mandatory nature of service charges may draw more attention to them than is drawn to voluntary tips, so consumers may incorporate service charges into their perceptions of restaurant expensiveness more than they incorporate voluntary tips. If so, then restaurants with automatic service charges should be perceived as more expensive than comparably priced restaurants with voluntary tipping.

Shuo Wang and I tested these ideas in a series of experiments presenting subjects with information about hypothetical restaurants - including information about their tipping policies, which were randomly varied across subjects - and asking them to rate the expensiveness of the restaurants. ${ }^{67}$ The results of those studies are summarized in Exhibit 4.4. We found that restaurants with voluntary tipping were perceived as significantly less expensive than restaurants with service charges, which in turn were perceived as less expensive than restaurants with 15-percent higher service-inclusive menu prices. Importantly, these effects held for big and small tippers alike, which means that even customers whose total costs (including tips) were lower under the no-tipping systems thought the restaurant was more expensive under those systems than under voluntary tipping. Furthermore, these effects were true even when customers were aware of the total combined costs of eating at the restaurant. These findings suggest that consumers treat tips and service charges separately from menu prices in their mental accounting of restaurant dining.

Exhibit 4.4. Consumers perceive restaurants with voluntary tipping as less expensive than restaurants with automatic service charges which are perceived as less expensive than restaurants with service inclusive pricing (rated expensiveness on a 7 point scale).

\begin{tabular}{|c|c|c|c|c|c|}
\hline $\begin{array}{l}\text { Source / Type of Service / } \\
\text { Restaurant Information Provided }\end{array}$ & $\begin{array}{l}\text { Voluntary } \\
\text { Tipping }\end{array}$ & $\begin{array}{l}\text { No Tipping } \\
\text { (15\% higher } \\
\text { menu } \\
\text { prices) }\end{array}$ & $\begin{array}{l}15 \% \\
\text { Service } \\
\text { Charge }\end{array}$ & $\begin{array}{l}18 \% \\
\text { Service } \\
\text { Charge }\end{array}$ & $\begin{array}{l}22 \% \\
\text { Service } \\
\text { Charge }\end{array}$ \\
\hline $\begin{array}{l}\text { Lynn \& Wang (2012:S1) / } \\
\text { Menu Service / Pictures \& Menu }\end{array}$ & $3.9^{\mathrm{a}}$ & $4.7^{\mathrm{d}}$ & $4.3^{\mathrm{b}}$ & $4.4^{\mathrm{bc}}$ & $4.7^{\text {cd }}$ \\
\hline $\begin{array}{l}\text { Lynn \& Wang (2012: S2) / } \\
\text { Menu Service / Pictures \& Menu }\end{array}$ & $4.6^{\mathrm{a}}$ & $4.9^{c}$ & $4.7^{\mathrm{b}}$ & $4.9^{c}$ & \\
\hline $\begin{array}{l}\text { Lynn \& Wang (2013) / } \\
\text { Menu Service / Pictures \& Menu }\end{array}$ & $3.5^{\mathrm{a}}$ & $4.1^{\mathrm{b}}$ & $3.6^{\mathrm{a}}$ & & \\
\hline $\begin{array}{l}\text { Wang (2013: S1) / } \\
\text { Brunch Service / Flyer Only }\end{array}$ & $3.3^{\mathrm{a}}$ & $4.2^{\mathrm{b}}$ & $3.6^{\mathrm{c}}$ & & \\
\hline $\begin{array}{l}\text { Wang (2013:S2) / } \\
\text { Brunch Service / Flyer Only }\end{array}$ & $3.4^{\mathrm{a}}$ & & $3.7^{\mathrm{b}}$ & & \\
\hline $\begin{array}{l}\text { Wang (2013:S3) / } \\
\text { Brunch Service / Flyer Only }\end{array}$ & $2.7^{\mathrm{a}}$ & $3.0^{\mathrm{b}}$ & & & \\
\hline
\end{tabular}


Three of the studies in Exhibit 4.4 also measured patronage intentions. In those studies, the effects of service charges (vs tipping) on perceived restaurant expensiveness decreased ratings of intentions to patronize the restaurants by $.00, .04$, and .17 , on a seven-point scale, while the effects of menu inclusive pricing (vs tipping) decreased ratings of intentions to patronize the restaurant by only .12 out seven points. These small indirect effects of the pricing system on patronage intentions through perceived expensiveness (holding actual expensiveness constant) do not give cause for alarm. However hypothetical scenarios seem likely to underestimate price effects on demand.

In summary, the evidence suggests that abandoning tipping will increase costs for, and decrease demand from, a substantial subset of restaurant customers. Unfortunately, it is impossible to accurately quantify this effect ahead of time. In addition, abandoning tipping will increase the perceived expensiveness of restaurants even among generous tippers who will see no real increase in their total costs. That effect will be stronger if tipping is replaced with higher service-inclusive menu prices than if it is replaced with automatic service charges, but again it is impossible to accurately quantify the effect on restaurant demand ahead of time. What we can say is that these negative effects on demand will be smaller for more expensive restaurants, because their customers are less price sensitive and fewer of their customers are substandard tippers who will see an increase in their real costs if tipping is abandoned.

\section{Does Tipping Increase (or Decrease) the Costs of Doing Business?}

Many people think tipping reduces the costs of doing business. While that is certainly true for some costs, it is also true that tipping increases other costs. To shed light on that issue, let's examine the major cost advantages and disadvantages of tipping.

How does tipping affect the costs of hiring?

Federal law and the laws of many states allow employers to count a portion of tip income toward minimum wage requirements. This tip credit allows restaurants to pay tipped workers less than they would otherwise have to be paid, so tipping clearly reduces payroll costs by the size of the tip-credit reduction (see Exhibit 5.1). Even though payrolls are somewhat reduced, cost savings are generally passed on to consumers in the form of lower menu prices. In fact, the excess pay that tipping often gives servers costs restaurants more in lost revenues from lower prices than they gain from payroll reductions, as I explained earlier. Thus, tipping may actually increase the net costs of hiring workers. 
Exhibit 5.1. The payroll savings provided by tipping increase with the (\$) tip credit, which differs across states as shown above.

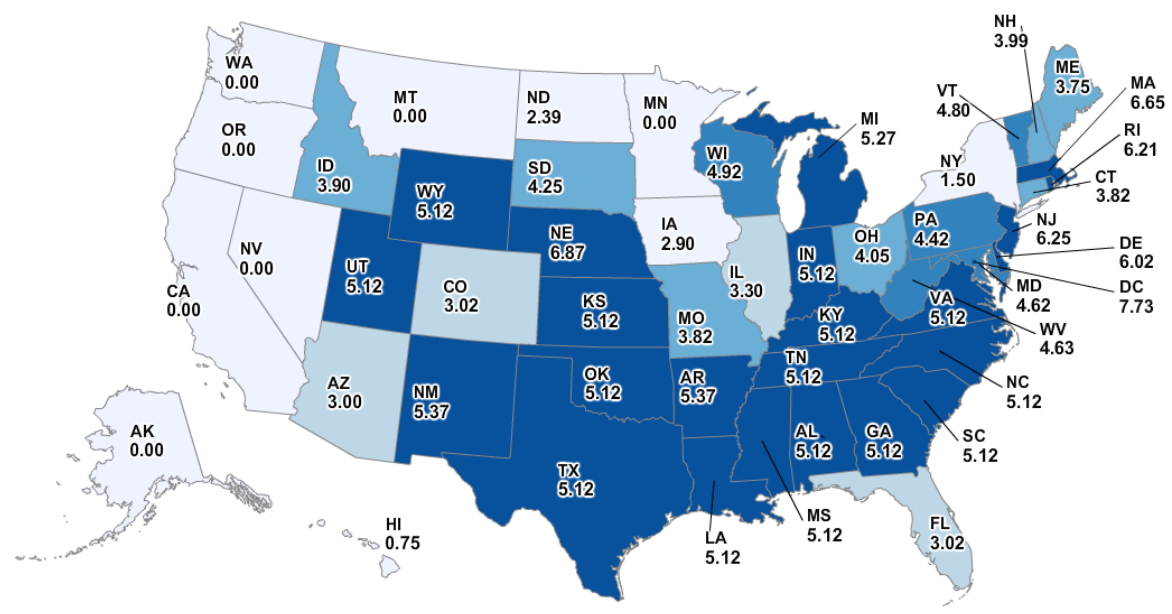

How does tipping affect sales-contingent costs (or commissions)?

Restaurants' taxes, rent, and marketing costs are often tied to sales figures. Tipping reduces these sales-contingent costs (or commissions) by reducing menu prices and, thus, sales totals. The benefit of those commission reductions is hidden by the reduced sales, but they are real. Basically, tipping allows restaurants to avoid paying commissions on a portion of their labor costs, which increases their profits. The following hypothetical example explains why.

Say that a restaurant with service-inclusive menu pricing generates $\$ 10,000 /$ month in sales from which it pays $\$ 3,500 /$ month in labor costs, $\$ 3,500 /$ month in food costs, and $\$ 2,500 /$ month in rent. Further, say that 20 percent of its sales come from Grub Hub, which charges a 13.5 percent commission. This restaurant would make a profit of $\$ 230 /$ month $[\$ 10,000$ sales $\$ 3,500$ labor - $\$ 3,500$ food $-\$ 2,500$ rent $-(\$ 2,000 \times .135=\$ 270)$ commission $=\$ 230$ profit $]$. Next assume that tipping is introduced at the restaurant allowing labor costs to be reduced by 15 percent of the old sales and all of the savings would go to reduced menu prices, with no other changes. Now the restaurant would make a profit of $\$ 270.50 /$ month $[\$ 8,500$ sales - $\$ 2,000$ labor - $\$ 3,500$ food $-\$ 2,500$ rent $-(\$ 1,700 \times .135=\$ 229.50)$ commission $=\$ 270.50$ profit $]$.

As this example illustrates, tipping does allow real savings on fixed commissions. However, similar savings can also be achieved with automatic service charges, which also reduce menu prices and the sales totals used to calculate commissions. Furthermore, because commissions are often negotiated rather than fixed, restaurants using service-inclusive menu pricing should 
be able to negotiate lower commissions than those paid by restaurants with tipping or service charges. Thus, restaurants need not keep voluntary tipping systems on account of the savings on fixed commissions that they provide.

How does tipping affect the costs of monitoring and motivating employees? Many economists argue that tipping exists because it is the most efficient way to monitor employees and motivate them to do a good job. ${ }^{68}$ The argument is that managers cannot always tell whether employees are delivering the kind of service their customers want, but customers can tell. Thus it is more efficient to have customers monitor and reward service via tipping. This belief that tipping exists because it provides the most efficient, or cost effective, way to monitor and motivate workers is supported by a recent study of mine looking at why people are more likely to tip some occupations than others. ${ }^{69}$ I found that the likelihood that service occupations involve tips increases as it becomes easier for customers than for managers to tell whether the workers in those occupations are doing a good job $(\mathrm{r}=.55, \mathrm{n}=122$ occupations, $\mathrm{p}<.001)$. This finding suggests that occupational differences in the efficiency of consumer monitoring contribute to occupational differences in the likelihood of a position being tipped. However, this does not demonstrate that tipping is a cost-effective way of monitoring and motivating service workers. In fact, I doubt that tipping is cost-effective, because it increases the need for managerial vigilance against employee theft and increases the difficulty of tracking, recording, and reporting servers' tip incomes, as I explain next. Thus, it is not even clear whether tipping has a net positive or negative effect on monitoring costs, much less whether that effect offsets its other costs.

How does tipping affect employee theft?

One of the less frequently considered costs of tipping is its encouragement of employee theft in the form of servers' giving customers free food and drinks in order to encourage larger tips. ${ }^{70}$ In fact, my previously mentioned survey of nearly 700 U.S. restaurant servers found that 20 percent admitted sometimes doing this, and another 10 percent admitted doing so often or all the time. ${ }^{71}$ Only 37 percent of the servers claimed to never give customers free stuff as a way to increase their tips (see Exhibit 5.2). This sample of servers was not representative, but analyses of the data indicated that the tendency to give customers free food and drink did not vary much across servers' geodemographic and workplace characteristics (see Exhibit 5.3). Thus, the results of this survey reasonably describe the behavior of many waiters and waitresses. Although it is not clear what the precise dollar value of the stolen food and drink is, it is clear that tipping motivates a substantial number of restaurant servers to engage in such theft. 
Exhibit 5.2. Thirty percent of servers admit at least sometimes giving customers free food or drinks in order to increase the tips those customers leave.

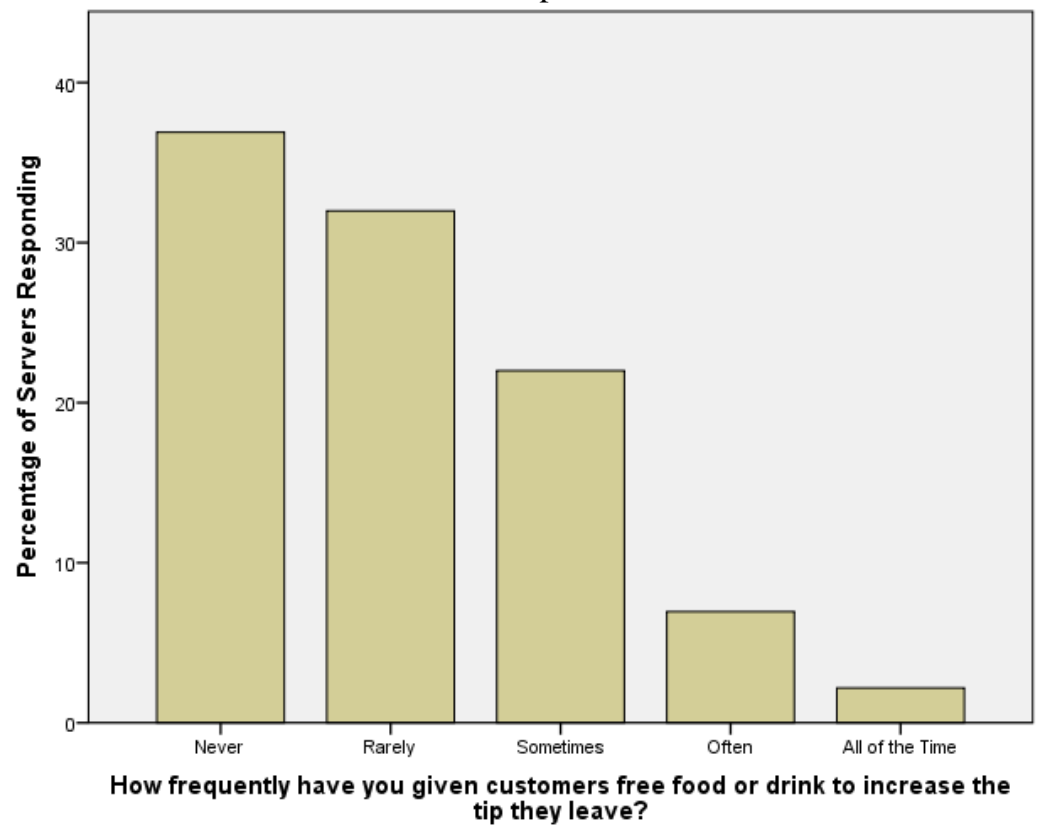

Exhibit 5.3. Servers' tendency to give away food and drinks as a way of increasing tips does not vary much across servers' geo-demographic and workplace characteristics (standardized regression coefficients).

\begin{tabular}{|c|c|}
\hline $\begin{array}{l}\text { Server } \\
\text { Characteristics/Predictors }\end{array}$ & Frequency of giving away food and drinks to increase tips. \\
\hline Age & $-.18^{* * * *}$ \\
\hline Female $^{\mathrm{a}}$ & $-.09 *$ \\
\hline White $^{\mathrm{a}}$ & .004 \\
\hline Married $^{\mathrm{a}}$ & -.04 \\
\hline Midwest ${ }^{b}$ & -.01 \\
\hline South ${ }^{\mathrm{b}}$ & -.001 \\
\hline West $^{\mathrm{b}}$ & -.01 \\
\hline Inexpensive Restaurant ${ }^{\mathrm{a}}$ & -.02 \\
\hline Moderately Expensive & .03 \\
\hline Restaurant ${ }^{\mathrm{a}}$ & \\
\hline Suburban Restaurant ${ }^{\mathrm{a}}$ & .04 \\
\hline Urban Restaurant ${ }^{\mathrm{a}}$ & .02 \\
\hline Lots of foreign customers ${ }^{\mathrm{a}}$ & .02 \\
\hline $\begin{array}{l}\text { Lots of ethnic minority } \\
\text { customers }^{\mathrm{a}}\end{array}$ & -.05 \\
\hline $\begin{array}{l}\text { Lots of elderly/retired } \\
\text { customers a }\end{array}$ & $.10 *$ \\
\hline $\mathrm{R}^{2}$ & $.05 * *$ \\
\hline $\mathrm{N}$ & 629 \\
\hline
\end{tabular}


How does tipping affect legal risks or costs?

The rules and regulations surrounding tipping are numerous and complex. Employers are required by law to report all their employees' incomes (including tips), to withhold employee taxes on that income, and to pay the employer share of FICA taxes on that income, even though the employer cannot be certain how much an employee makes in cash tips. ${ }^{72}$ Furthermore, various employment laws and regulations require employers of tipped workers to (1) notify affected employees of their intention to claim a tip credit and of any tip pooling or sharing arrangements, (2) apply the tip-credit allowance only for employees earning sufficient tips and only for hours worked in which 80 percent or more of employees' time was spent on tipearning duties, and (3) ensure that only tip-eligible employees participate in tip-pooling or sharing arrangements. ${ }^{73}$ Documenting compliance with these requirements is costly and failure to comply or to document that compliance can be even more costly. Data on the total tipping-related tax penalties, lawsuit settlement amounts, court-ordered judgments, and legal fees incurred by restaurants each year are unavailable, but it is clear that the costs are often substantial for those restaurants involved. For example, Lehigh Valley Restaurant Group (a Red Robin franchisee) settled a tipping-related lawsuit for \$1.3 million, Sushi Yasuda settled for \$2.4 million, and Mario Batali, for $\$ 5.25$ million. $^{74}$

One final potential legal risk of tipping deserves discussion. Consumers' may tip ethnic minority servers less than they do white servers, and this may represent an adverse impact that would make the use of tipping to compensate employees an unlawful business practice under Title VII of the Civil Rights Act of $1964 .^{75}$ The legal issues involved are complex and beyond the scope of this report, but a number of legal scholars and practicing lawyers have acknowledged that this theory of the law is plausible and that a possible class-action lawsuit alleging adverse impact from tipping could prevail. ${ }^{76}$ Such a lawsuit would require the plaintiff to prove the adverse impact claim, which a small number of studies suggest may be achievable. In one study, Ian Ayres and his co-authors found that black taxicab drivers in New Haven, Connecticut, received smaller tips from both black and white passengers than did white cab drivers. ${ }^{77}$ In two other studies, my co-authors and I found that black waiters and waitresses in Oxford, Mississippi, and Detroit, Michigan, received smaller tips from both black and white customers than did white waiters and waitresses and that those differences in tip income could not be attributed to differences in service delivery. ${ }^{78}$ These studies involved only a small number of cab drivers and restaurant servers, so I do not believe that they are sufficient to establish adverse impact. However, they do persuade me that tipping is more likely than not to have an adverse impact on black servers' incomes and that efforts to find more evidence of such an adverse 
impact through discovery or other means are likely to succeed. Thus, I believe that the risk of a class-action lawsuit alleging adverse impact from tipping is real and that it provides another reason that restaurant chains with an ethnically diverse wait staff should consider abandoning tipping.

In summary, it is clear that tipping decreases some specific costs of doing business and increases others. Whether the net costs of doing business are generally higher or lower under tipping than under its alternatives is unclear and probably varies significantly across restaurants. For example, restaurateurs in California who face a high minimum wage and no tip credit see smaller payroll savings from tipping and greater potential revenue gains from replacing excessive server tip income with more reasonable wages that are supported by service charges or higher menu prices than do restaurateurs in Texas who face a relatively low minimum wage and a large tip credit. Thus, California restaurateurs should anticipate more cost advantages and fewer cost disadvantages from abandoning tipping than should the Texans.

\section{Conclusions}

In conclusion, the evidence suggests that tipping has numerous advantages and disadvantages compared to service charges or higher service-inclusive menu prices. However, most of those advantages and disadvantages are only modest in size or importance and many offset one another. For example, tipping helps to selectively attract and retain better workers who like the performance contingent nature of tip income, but those effects are weak. Stronger effects are found for tipping's enhancement of employee motivation to deliver friendlier and more personalized service, but those effects are offset to some extent by its discouragement of employee cooperation and its encouragement of service discrimination against members of consumer groups perceived to be poor tippers. Given their modest size or offsetting nature, I believe that the effects of different tipping systems on employee attraction and retention, service quality, customer satisfaction, and the costs of operation can generally be set aside or ignored when choosing between those systems. ${ }^{79}$

Overall, I come away from the data believing that biggest reason for restaurateurs to replace tipping is that it takes revenue away from them in the form of lower prices and gives it to servers in the form of tip income that is excessively high compared to other restaurant employees. The biggest reason for restaurateurs to keep tipping, on the other hand, is that it allows them to reduce menu prices, which increases demand. Thus, restaurateurs' decisions regarding whether to keep voluntary tipping should depend on the relative strengths of these potential benefits and harms. The more that a restaurant's servers are overpaid relative to the back of house and the wealthier and less price-sensitive a restaurant's customers are, the more the owner of that 
restaurant should consider abandoning tipping. By this reasoning, many upscale, expensive restaurants (especially those in states with no or small tip credits) probably should replace tipping with one of its alternatives, because they tend to have a high pay discrepancy between front and back of house, have few small tippers who would face a real price increase, and have price insensitive customers.

Depending on the laws of the state a restaurant operates in, restaurateurs may have more control over revenue from menu prices than over revenue from service charges and should choose the higher menu price option when that is the case. However, when state laws allow restaurateurs to distribute service charges as they see fit, then service charges should be preferred over higher menu prices because service charges have a smaller effect on perceptions of restaurant expensiveness than do comparable increases in menu prices. Consumers do like higher menu prices more than service charges, but that preference is not likely to appreciably affect patronage. Furthermore, consumers' dislike of service charges is likely to fade as consumers become more familiar with this compensation system.

A final comment goes beyond the research data but deserves to be made. Restaurants that abandon tipping should prohibit employees from accepting tips and should not give customers the option of adding a tip even though many will want to do so. The reason for this is that once a few people start tipping, it puts social pressure on others to do the same, which only increases the number of tippers and subsequent social pressure on non-tippers. ${ }^{80}$ In other words, restaurateurs need to protect their customers who prefer not to tip from social pressures created by the few customers who do want to tip. Otherwise, restaurateurs will ultimately find customers reluctantly tipping normal amounts on top of their service charges or high, service-inclusive menu prices and that added cost will undoubtedly reduce demand. I have only anecdotal evidence to support this concern, but caution restaurateurs replacing tipping with service charges or higher service-inclusive menu prices that they need to kill tipping and not simply abandon it at their establishments.

\section{NOTES AND REFERENCES}

1. For example, see: Palmer, B. (2013), “Tipping Is an Abomination,” http:// www.slate.com/articles/business/moneybox/2013/07/abolish_tipping_it_s_bad_for_ servers_customers_and_restaurants.html; Porter, J. (2013), "What Happens when You Abolish Tipping?" http://www.slate.com/articles/life/culturebox/2013/08/tipless_restaurants_the_linkery_s_owner_explains_why_abolishing_tipping.html; Bershidsky, L. (2015), "No Tipping Means More Great Restaurants," http:// www.bloombergview.com/articles/2015-10-15/u-s-restaurant-tipping-doesn-t-meanbetter-quality-restaurants; Grimminck, R. (2015), “10 Reasons to Abolish the Tipping 
System in Restaurants," http://www.toptenz.net/10-reasons-to-abolish-the-tippingsystem-in-restaurants.php

2. Infante, D. (2015), "All the Restaurants across the USA that Have Banned Tipping," https://www.thrillist.com/eat/nation/american-restaurants-don-t-allowtipping-usa-restaurants-banned-tipping

3. Frost, P. (2015), "Is Tipping Becoming Obsolete?" http://www.chicagobusiness.com/article/20151114/ISSUE01/311149992/is-tipping-becoming-obsolete

4. Cohen, P. (2015), “As Minimum Wages Rise, Restaurants Say No to Tips, Yes to Higher Prices," http://www.nytimes.com/2015/08/24/business/economy/asminimum-wage-rises-restaurants-say-no-to-tips-yes-to-higher-prices.html?_r=0

5. Rainey, C. (2015), "The Latest Restaurant to Abolish Tipping Offers Workers a \$35K Salary Instead," www.grubstreet.com/2015/01/pittsburgh-restaurant-paysservers-35000-a-year-salary.html

6. Frost, P., op. cit.

7. Meszaros, E. (2015), “2015 Top Story: Abandoned Tip: Restaurants Rethink Tipping Policies," https://www.specialtyfood.com/news/article/2015-top-storyabandoned-tip-restaurants-rethink-tipping-policies/

8. Cohen P., op. cit.

9. Ibid.

10. Cohen, P., op. cit.

11. DeRusha, J. (2016), "De Rusha Eats: These Restaurants Have Banned Tipping, Raised Wages," http://minnesota.cbslocal.com/2016/01/07/derusha-eatsthese-restaurants-have-banned-tipping-raised-wages/

12. Ibid.

13. Cole, W. (1989), "Leaving Tips," Time, February 27: 54; Frumpkin, P. (1988), “The Great Tipping Debate," Restaurant Business, July 20: 113-120; and Parise, M. (1987), “Optional Tipping Has Seen Its Day,” Nation's Restaurant News, March 9: F50.

14. Seagrave, K. (1998), Tipping: An American Social History of Gratuities. Jefferson, NC: McFarland and Co; Wilk, D.L. (2015), “The Red Cap's Gift: How Tipping Tempers the Rational Power of Money," Enterprise and Society 16(1): 5-50.

15. Lynn, M. (2006), "Tipping and Its Alternatives: When and Why to Choose Voluntary Tipping, Service Charges, or Service-inclusive Pricing Policies," Cornell Hospitality Report 6(5): 6-16; Lynn, M., and G. Withiam (2008), "Tipping and Its Alternatives: Business Considerations and Directions for Research," Journal of Services Marketing 22(4): 328-336.

16. Allegretto, S., and D. Cooper (2014), Twenty-three Years and Still Waiting for Change. Washington, DC: Economic Policy Institute Report.

17. I.R.S. (1984), Tip Income Study, Department of the Treasury, Research Division, Publication 1530 (8-90), catalog Number 12482K; Williams, B., and M. Genest (2015), Estimating Hourly Tip Income for Waiters and Waitresses in Fullservice Restaurants in California. Capital Matrix Consulting report prepared for California Restaurant Association.

18. See O’Neil, C. (2015), "Pitting Poor against Poorer in the Fight for Tips," http://billmoyers.com/2015/10/26/if-restaurants-eliminate-tipping-who-wins/; Wells, P. (2013), "Leaving a Tip: A Custom in Need of Changing?" http://www.nytimes. 
com/2013/09/04/dining/leaving-a-tip-a-custom-in-need-of-changing.html?page wanted $=$ all.

19. Front-of-house positions do require language and social skills, as well as levels of personal appearance, not typically required of back-of-house positions. However, waiters and waitresses also make more than do other less frequently tipped front-of-house workers such as cashiers, hosts, and reservationists whose jobs require comparable appearances, language skills and social skills. Furthermore, many back-of-house positions such as pastry and line cooks require more job specific skills and training than do front-of-house positions. Thus, it is reasonable to argue that paying waiters and bartenders more than cooks and hosts is probably unnecessary to get competent workers to fill the former positions.

20. See Occupational Employment Statistics, http://www.bls.gov/oes/home.htm

21. NYC Hospitality Alliance (2015), New York City Restaurant Industry Compensation and Benefits Report. This report also indicates that servers' median wages exceeded those of delivery people by $162 \%$, of cashiers by $129 \%$, of reservationists by $83 \%$, of maître d's by $58 \%$, and of human resource coordinators by $36 \%$.

22. Batt, R., J.E. Lee, and T. Lakhani (2014), A National Study of Human Resource Practices, Turnover, and Customer Service in the Restaurant Industry. http://rocunited.org/a-national-study-of-human-resource-practices-turnover-andcustomer-service-in-the-restaurant-industry/

23. PayScale's Restaurant Report: Key Stats (2015), http://www.payscale.com/ data-packages/restaurant-report/full-data

24. Batt, R., J.E. Lee, and T. Lakhani, loc. cit.

25. See Eater Staff (2015), “A Restaurant Server Explains Why We Shouldn't Abolish Tipping," http://www.eater.com/2015/3/13/8187659/restaurant-serverexplains-why-we-should-not-abolish-tipping, and NBCNews.com (2013), "Should American Restaurants Abolish Tipping?" http://www.nbcnews.com/business/shouldamerican-restaurants-abolish-tipping-6C10285252.

26. Lynn, M., R. Kwortnik, and M. Sturman (2011), "Voluntary Tipping and the Selective Attraction and Retention of Service Workers in the U.S.A.: An Application of the ASA Model," International Journal of Human Resource Management 22(9): 1887-1901.

27. Parise, op. cit.

28. In early 2014, over 8000 consumers from across the U.S. rated the service of up to eight different restaurants they had patronized within the last six months. Only ratings of family-dining or full-service restaurants were used in the analyses. Standardized residuals were obtained from eight regression models predicting these service ratings from frequency of eating at restaurants for breakfast, for lunch, for dinner and for other occasions, respondents' age, sex, race (white/non-white), education, income, employment $(\mathrm{Y} / \mathrm{N})$, marital status (married/not married), parental status (children $<18 /$ no children $<18$ ), residence area (urban, suburban, vs. rural), and restaurant id. Those standardized ratings were then averaged within individuals and the resulting index was averaged across individuals within each state. State averages based on 20 or more respondents were used in the reported analyses. 
29. The regression coefficient for pay-premium (measured in dollars) from an equation predicting standardized service ratings was .016 and the standard deviation of raw service ratings on a five point scale was about $.9(.016 \times .9=.014)$.

30. Lynn, M. (2016a), MTurk Tipping Survey, unpublished data set.

31. See Lynn, M. (2003), "Tip Levels and Service: An Update, Extension and Reconciliation," Cornell H.R.A. Quarterly 42: 139-148; Lynn, M., R. Kwortnik, and M. Sturman, op. cit.; Lynn, M. (2016b), "Does Tipping Help to Attract and Retain Better Service Workers?” Journal of Foodservice Business Research 20(2). Forthcoming.

32. For example, tipping is thought to help attract more service-oriented workers because service-oriented workers earn more and like working for tips more and greater income and satisfaction with mode of compensation should increase job attractiveness/satisfaction. Since service-orientation shares only about 3 percent of its variation each with average tip size and attitude toward working for tips and each of these variables share only about 6 and 10 percent of their variation with job satisfaction respectively, then tipping will increase the percentage of variance that workers' service-orientation shares with job satisfaction by only about 0.5 points $((.03 \mathrm{x}$ $.06)+(.3 \times .10)=.0048)$. Those interested in attracting and retaining the best workers should focus on key drivers of the other 99.5 percent of the variance shared between server service-orientation and job satisfaction rather than on tipping.

33. See Lynn, M., and G. Withiam, op. cit.

34. See Lynn, M., and S. Wang (2013), "The Indirect Effects of Tipping Policies on Patronage Intentions through Perceived Expensiveness, Fairness and Quality," Journal of Economic Psychology 29: 62-71.

35. See Lynn, M. (2001), "Restaurant Tipping and Service Quality: A Tenuous Relationship," Cornell H.R.A. Quarterly 42: 14-20; Parise, M., op. cit.

36. Frumkin, P., op. cit.

37. Google Consumer Survey (2012), titled "Tipping Etiquette," https://www. google.com/insights/consumersurveys/view?survey=ktnl73zdqo6va; Kalpana, C. (2013), "Tipping in Restaurants: How Do Americans Feel?," https://www.survey monkey.com/blog/2013/04/18/tipping-in-restaurants/; Dobkin, K. (2013), "Holiday Tipping Survey: How Much Do You Give?," https://www.zagat.com/b/holidaytipping-survey-how-much-do-you-give; TripAdvisor (2014), “Americans Most Gratuitous When It Comes to Tipping on Vacation," according to TripAdvisor survey, http://ir.tripadvisor.com/releasedetail.cfm?ReleaseID=856168; Pilon, A. (2014), "Tipping Survey: Two-thirds Always Tip Restaurant Servers," https://aytm.com/blog/ daily-survey-results/tipping-survey-2/; Audience Research Analysis (2015), A Study of Frequent NYC Diners. Unpublished report to NYC Hospitality Alliance.

38. Lynn, M. (2016a), loc. cit.

39. Wang, S. (2013), The Effects of Price Partitioning and Its Implications for Menu Pricing. Unpub. Ph.D. diss., Cornell University, Ithaca, NY; Lynn, M., and S. Wang (2013), "The Indirect Effects of Tipping Policies on Patronage Intentions through Perceived Expensiveness, Fairness, and Quality," Journal of Economic Psychology 39: 62-71.

40. All four of these indirect effects of tipping policy on likelihood of patronage through perceived fairness of the tipping policy were statistically significant at the .05 level. 
41. Mills, S., and H. Riehle (1987), "What Customers Think about Tips vs. Service Charges," Restaurants USA October: 20-21.

42. See Lynn, M., and S. Wang, op. cit. This study presented respondents with a restaurant menu containing the tipping policy manipulation as well as interior and exterior pictures of the restaurant and asked them to rate the expected service levels at that restaurant as well as the fairness of the tipping policy and the likelihood of patronizing the restaurant.

43. The effect of service inclusive menu pricing (vs voluntary tipping) on service expectations and its indirect effect on patronage likelihood through service expectations were both statistically reliable at the .05 level.

44. See Wall, E., and L. Berry (2007), "The Combined Effects of the Physical Environment and Employee Behavior on Customer Perception of Restaurant Service Quality," Cornell H.R.A. Quarterly 48: 59-69.

45. Lynn, M. (2001), op. cit.

46. Lynn, M., R. Kwortnik, and B. Ross (2009), "Buyer Monitoring: A Means to Insure Personalized Service," Journal of Marketing Research XLVI: 573-583; Lynn, M., R. Kwortnik, and M. Sturman (2011), op. cit.; Lynn, M. (2016b), op. cit.

47. Lynn, M. (2016b), op. cit.

48. Lynn, M., R. Kwortnik, and B. Ross, op. cit.

49. Deci, E., R. Koestner, and R. Ryan (1999), "A Meta-analytic Review of Experiments Examining the Effects of Extrinsic Rewards on Intrinsic Motivation," Psychological Bulletin 125: 627-668.

50. Grandey, A., et. al. (2005), "Is Service with a Smile Enough? Authenticity of Positive Displays during Service Enocunters," Organizational Behavior and Human Decision Processes 96: 38-55.

51. Curtis, C., R. Upchurch, and D. Severt (2009), "Employee Motivation and Organizational Commitment: A Comparison of Tipped and Non-tipped Employees," International Journal of Hospitality and Tourism Administration 10: 253-269.

52. Brewster, Z., and J. Wills (2013), "The Institution of Tipping as a Source of Employee Agency: The Case of Restaurant Servers," Sociological Focus 46: 193210; Paules, G. (1991), Dishing it Out: Power and Resistance among Waitresses in a New Jersey Restaurant. Philadelphia, PA: Temple University Press; Wilk, D., op. cit.; Lynn, M., R. Kwortnik, and B. Ross (2009), "Buyer Monitoring: A Means to Insure Personalized Service," Journal of Marketing Research XLVI: 573-583; Lynn, M., R. Kwortnik, and M. Sturman (2011), op. cit.; Lynn, M. (2016b), op. cit.

53. Fang, M., and B. Gerhart (2012), "Does Pay for Performance Diminish Intrinsic Interest?” International Journal of Human Resource Management 23: 11761196; Grandey, A., N. Chi, and J. Diamond (2013), "Show Me the Money! Do Financial Rewards for Performance Enhance or Undermine the Satisfaction from Emotional Labor?” Personnel Psychology 66: 569-612.

54. Barkan, R., and A. Israeli (2004), "Testing Servers' Roles as Experts and Managers of Tipping Behavior," Service Industries Journal 24: 1-18; Brester, Z. (2013), "The Effects of Restaurant Servers' Perception of Customers' Tipping Behaviors on Service Discrimination," International Journal of Hospitality Management 32: 228-236; Kim, K. (2012), The Effects of Perceived Visible Characteristics of Customers on Servers' Tipping Expectations. Unpub. M.A. thesis, University of 
Missouri, Columbia, MO; Shrestha, J. (2010), Tipping Differences of Domestic and Foreign Customers in Casual Dining Restaurants: An Investigation of Customers' and Servers' Perception. Unpub. M.A. thesis, Oklahoma State University, Stillwater, OK.

55. This unpublished data from the same survey used in Lynn, M. (2016b), op. cit.

56. These results are also similar to those from an earlier server survey reported by McCall, M., and A. Lynn (2009), "Restaurant Servers' Perceptions of Customer Tipping Intentions," International Journal of Hospitality Management 28: 594-596.

57. Frumkin, P., op. cit.

58. Barkan, R., et al. (2004), "Tip Policy, Visibility and Quality of Service in Cafes," Tourism Economics 10: 449-462.

59. Zakay, S. (2013), Free Riding or Competition? Analyzing the Choice of Compensation Structure in New York City Restaurants. Unpub. Senior Honors Thesis, Columbia University, NYC.

60. Lynn, M., R. Kwortnik, and B. Ross, op. cit.; Lynn, M. and R. Kwortnik, op. cit.

61. This makes tipping a form of price discrimination, which enhances sales and profits as long as "consumers differ in the amounts they are willing to pay, the prices charged match the different segments' willingness to pay, and demand from pricesensitive customers is lower than the firm's production capacity" (Lynn, M., and G. Withiam, op. cit.).

62. Okrent, A., and J. Alston (2012), The Demand for Disaggregated Foodaway-from-home and Food-at-home Products in the United States. Economic research report No. 139, U. S. Department of Agriculture; Okrent, A., and A. Kumcu (2014), "What's Cooking? Demand for Convenience Foods in the United States," paper presented at the Agricultural and Applied Economics Association's AAEA Annual Meeting, Minneapolis, MN, July 27-29.

63. Richards, T., and L. Mancino (2014), "Demand for Food-away-from-home: A Multiple-discrete-continuous Extreme Value Model," European Review of Agricultural Economics 41: 111-133.

64. This is an unpublished finding from a survey used in Lynn, M. (2009), "Individual Differences in Self-attributed Motives for Tipping: Antecedents, Consequences, and Implications," International Journal of Hospitality Management 28: 432-438.

65. Hymel, K., and K. Small (2015), "The Rebound Effect for Automobile Travel: Asymmetric Response to Price Changes and Novel Features of the 2000s," Energy Economics 49: 93-103; Kalyanaram, G., and R. Winer (1995), "Empirical Generalizations from Reference Price Research," Marketing Science 14: 161-169.

66. Greenleaf, E., et al. (2016), "The Price Does Not Include Additional Taxes, Fees, and Surcharges: A Review of Research on Partitioned Pricing," Journal of Consumer Psychology 26(1): 105-124.

67. Lynn, M., and S. Wang (2012), "The Effects of Tipping on Perceived Restaurant Expensiveness: Implications for Price Partitioning and Employee Compensation," unpub. ms., Cornell University, Ithaca, NY; Lynn, M., and S. Wang (2013), op. cit.; Wang, S., op. cit.

68. Bodvarsson, O., and W. Gibson (1994), "Gratuities and Customer Appraisal of Service: Evidence from Minnesota Restaurants," Journal of Socio-Economics 23: 287-302; Jacob, N., and A. Page (1980), "Production, Information Costs, and 
Economic Organization: The Buyer Monitoring Case," American Economic Review 76: 476-478; Hemenway, D. (1984), Prices and Choices: Microeconomic Vignettes. Cambridge, MA: Ballinger.

69. Lynn, M. (2016), "Occupational Differences in the Receipt of Service Gratuities or Tips: Theory, Evidence, and Implications," Journal of Economic Psychology 54: $134-150$.

70. Brady, M., C. Voorhees, and M. Brusco (2012), "Service Sweethearting: Its Antecedents and Customer Consequences," Journal of Marketing 76: 81-98; Lynn, M., and S. Wang (2013), op. cit.

71. This is unpublished data from the survey reported in Lynn (2016b), op. cit.

72. Anonymous (2013), "Three Challenges Tipped Employees Present to Employers," http://www.paychex.com/articles/payroll-taxes/three-challenges-tippedemployees-present

73. Ruzal, J. (2014), "Tip-related Claims Will Continue to Be Served Up as the Lawsuit Du Jour against the Hospitality Industry in 2015," http://www.ebglaw. com/news/tip-related-claims-will-continue-to-be-served-up-as-the-lawsuit-du-jouragainst-the-hospitality-industry-in-2015/

74. Harris, J. (2015), "Red Robin Franchisee Settles Tip-sharing Lawsuit for \$1.3 Million," http://www.mcall.com/business/mc-red-robin-settles-wage-lawsuit20151203-story.html; Rainey, C. (2014), "Sushi Yasuda Agrees to Pay \$2 Million to Settle Tipping Lawsuit," http://www.grubstreet.com/2014/05/yasuda-lawsuit.html; Satran, J. (2012), "Mario Batali Settles Tip Lawsuit for \$5.25 Million," http:// www.huffingtonpost.com/2012/03/07/mario-batali-lawsuit_n_1325304.html

75. Lynn, M., and G. Withiam, op. cit.

76. Kline, J. (2016), "Fifteen Percent or Less: A Title VII Analysis of Racial Discrimination in Restaurant Tipping," Iowa Law Review 101: 1651-1680; Pandya, S. (2015), "Tipping as Employment Discrimination?" http://lawprofessors.typepad. com/laborprof_blog/2015/11/tipping-as-employment-discrimination.html

77. Ayres, I., F. Vars, and N. Zakariya (2005), "To Insure Prejudice: Racial Disparities in Taxicab Tipping," Yale Law Journal 114: 1613-1674.

78. Brewster, Z., and M. Lynn (2014), "Black-White Earnings Gap among Restaurant Servers: A Replication, Extension and Exploration of Consumer Racial Discrimination in Tipping," Sociological Inquiry 84: 545-569; Lynn, M., et al. (2008), "Consumer Racial Discrimination in Tipping: A Replication and Extension," Journal of Applied Social Psychology 38: 1045-1060.

79. Exceptions to this conclusion would be cases where circumstances make one or more of these effects particularly strong. For example, tipping makes it harder to recruit wait-staff in areas populated by groups perceived to be poor tippers and it motivates servers who are hired to deliver poorer service to these groups than to other customers. Restaurants in areas with a very large elderly, minority or foreign clientele may find that these effects are sufficiently strong to justify the replacement of tipping with one of its alternatives.

80. Lynn, M. (2015), "Service Gratuities and Tipping: A Motivational Framework," Journal of Economic Psychology 46: 74-88; Margoliath, Y. (2006), "The Case against Tipping," U.PA. Journal of Labor and Employment Law 9: 117-145. 
Reproduced with permission of copyright owner. Further reproduction prohibited without permission. 